\title{
Geochemical characterisation of the thermo-mineral waters of Greece
}

\author{
Lorenza Li Vigni · Kyriaki Daskalopoulou • Sergio Calabrese • \\ Konstantinos Kyriakopoulos • Francesco Parello • Filippo Brugnone • \\ Walter D'Alessandro
}

Received: 24 August 2020/ Accepted: 3 June 2021 / Published online: 12 June 2021

(C) The Author(s) 2021

\begin{abstract}
Geothermal areas of Greece are located in regions affected by recent volcanism and in continental basins characterised by elevated heat flow. Many of them are found along the coast, and thus, water is often saline due to marine intrusion. In the current study, we present about 300 unpublished and literature data from thermal and cold mineral waters collected along Greece. Samples were analysed for major ions, $\mathrm{Li}$, $\mathrm{SiO}_{2}$ and isotopes in water. Measured temperatures range from 6.5 to $98{ }^{\circ} \mathrm{C}$, $\mathrm{pH}$ from 1.96 to 11.98 , while Total Dissolved Solutes (TDS) from 0.22 to $51 \mathrm{~g} / \mathrm{L}$. Waters were subdivided into four main groups: (1)
\end{abstract}

Supplementary Information The online version contains supplementary material available at https://doi.org/10.1007/ s10653-021-01001-1.

L. L. Vigni - S. Calabrese · F. Parello · F. Brugnone University of Palermo, DiSTeM, via Archirafi 36, Palermo, Italy

K. Daskalopoulou

University of Potsdam, Institute of Geosciences, KarlLiebknecht-Str. 24-25, Potsdam Golm, Germany

K. Daskalopoulou

GeoForschungs Zentrum, Physics of Earthquakes and

Volcanoes, Helmholtzstraße 6/7, Potsdam, Germany

S. Calabrese · W. D’Alessandro ( $\square)$

Istituto Nazionale Di Geofisica E Vulcanologia, Sezione

Di Palermo, via Ugo La Malfa 153, Palermo, Italy

e-mail: walter.dalessandro@ingv.it thermal; (2) cold; (3) acidic $(\mathrm{pH}<5)$; and (4) hyperalkaline $(\mathrm{pH}>11)$. On statistical basis, thermal waters were subdivided into subgroups according to both their temperature [warm $\left(<29^{\circ} \mathrm{C}\right)$, hypothermal $\left(29-48^{\circ} \mathrm{C}\right)$, thermal $\left(48-75^{\circ} \mathrm{C}\right)$ and hyperthermal $\left(>75^{\circ} \mathrm{C}\right)$ ] and TDS [low salinity $(<4 \mathrm{~g} / \mathrm{L})$, brackish $(4-30 \mathrm{~g} / \mathrm{L})$ and saline $(>30 \mathrm{~g} / \mathrm{L})]$. Cold waters were subdivided based on their $p \mathrm{CO}_{2}$ [low $(<0.05$ atm $)$, medium (0.05-0.85 atm) and high (>0.85 atm)]. $\delta^{18} \mathrm{O}-\mathrm{H}_{2} \mathrm{O}$ ranges from -12.7 to $+2.7 \%$ versus SMOW, while $\delta^{2} \mathrm{H}-\mathrm{H}_{2} \mathrm{O}$ from -91 to $+12 \%$ versus SMOW being generally comprised between the Global Meteoric Water Line and the East Mediterranean Meteoric Water Line. Positive $\delta^{18} \mathrm{O}$ shifts with respect to the former are mostly related to mixing with seawater, while only for a few samples these shifts

\footnotetext{
K. Kyriakopoulos

Faculty of Geology and Geoenvironment, National and Kapodistrian University of Athens, Panestimioupolis, Ano Ilissia, Greece
} 
point to high-temperature water-rock interaction processes. Only a few thermal waters gave reliable geothermometric estimates, suggesting reservoir temperatures between 80 and $260{ }^{\circ} \mathrm{C}$.

Keywords Hydrogeochemistry - Stable isotopes · Carbon dioxide $\cdot$ Geothermometry

\section{Introduction}

In the 1960s, the National Tourism Organisation (NTO, 1966) estimated the number of thermo-mineral springs in Greece at more than 750, with nearly 200 of which found on the islands of the Aegean Sea. Even though about a quarter of these springs is nowadays used for balneotherapeutic purposes, archaeological evidence supports the use of some of them since prehistoric times (Fytikas et al., 1999). In classical times until the end of the Roman Empire, thermomineral waters were highly appreciated and many of them were mentioned by poets (Homer, Pindar, Aristophanes), historians (Herodotus, Diodorus Siculus, Plutarch) and geographers (Strabo, Pausanias) (Fytikas et al., 1999). At the same time, the first theories regarding their origin were developed (Plato, Aristotle) and their medical use was emphasised (Hippocrates). It is worth mentioning that, during this period, many thermo-mineral springs were considered sacred and were dedicated either to the Nymphs or to Asclepius, the God of Medicine. Their religious significance continued until Christian times. Then, this dedication shifted either to Virgin Mary or to Agioi Anargyroi, with the latter being saints known for offering their medical services without reward (Håland, 2009). Their balneotherapeutic use declined under the Byzantine Empire and grew again under the Ottoman Empire, but it was not before the end of the twentieth century that other uses (heat and energy production, industrial use of $\mathrm{CO}_{2}$, etc.) were applied (Fytikas, 1988). In fact, Fytikas et al. (2005) documented that in the early 70's the Institute of Mineral and Geological Exploration (IGME) used for the first time the thermal water for greenhouse heating. However, the great development in geothermal field arrived in 1981 when Greece entered the European Union, and many research projects were funded by the European Commission.
Greece, located in a geodynamically active area of the Eastern Mediterranean, is characterised by widespread geothermal resources closely linked to the geology of the country (Papachristou et al., 2019). Its puzzling geodynamic regime contributes to the existence of an elevated terrestrial heat flow, which results in several geothermal fields containing both low and intermediate temperature fluids (Fytikas \& Kolios, 1979). Areas of enhanced heat flow are located in regions affected by Miocene or Quaternary volcanism and in continental basins (Fytikas \& Kolios, 1979). Geothermal exploration has found high-enthalpy geothermal fields in Milos and Nisyros islands, in the South Active Aegean Volcanic Arc (SAAVA), and low-medium enthalpy georesources in some Aegean islands, i.e. Chios, Lesvos and Samothraki, and in several sedimentary basins of Northern and Central Greece (Mendrinos et al., 2010). Besides, many of these fields are found along the coast as well as in islands, and thus, thermal waters are often brackish to saline due to marine intrusion into the costal aquifer (Lambrakis \& Kallergis, 2005). In fact, according to Minissale et al. (1997), the thermal springs located in the SAAVA are affected by mixing between the local meteoric waters and the Aegean seawater, while a marine component, sometimes evolved due to processes seated in the deep thermal reservoirs, is found also in hot waters emerging along the coast of the continental basins (Duriez et al., 2008).

The complex geodynamic and geological setting of the Aegean territory reflects in a great variety of geochemical compositions for many thermal and cold fluid manifestations (Daskalopoulou et al., 2018a, 2019a; Minissale et al., 1989, 1997). The first scientific investigations regarding the chemical composition of the thermo-mineral waters of Greece appeared soon after the birth of the Modern Greek State in 1830. Landerer (1843) gave the first overview of the whole territory and further nationwide studies appeared in more recent times (Athanasoulis et al., 2009; Lambrakis \& Kallergis, 2005; Lambrakis et al., 2014; Pertessis, 1937).

The scope of this study is to present a large dataset on the chemical and isotopic composition of the thermo-mineral waters of the whole Greek country and discuss their properties in the framework of the geological context of the area. To this aim, we discussed the results of 285 water samples collected from October 2004 to March 2020 (Fig. 1) and 
analysed for their major, minor and trace constituents and the isotopic composition of water. About one third of the results were previously published (D'Alessandro et al., 2008, 2014, 2017, 2018, Li Vigni et al., 2021; Papachristou et al., 2014) and are here discussed together with the unpublished data to present a more or less complete picture of the whole country. Although spanning over a long time period, the same sampling and analytical methods were applied increasing the internal consistency of the dataset.

\section{Study area}

The complex geodynamic setting of the Hellenic territory classifies it in the most tectonically and seismically active areas of the world (e.g. Le Pichon et al., 2001; Taymaz et al., 1991; Tsokas \& Hansen, 1997). This regime is dominated by three large-scale tectonic structures: (1) the active retreat of the northward subduction of African plate beneath the Eurasian at a rate of 4-6 mm/a (McClusky et al., 2000) forming the back-arc Aegean area; (2) the mostly N-S oriented crustal extension (Mercier, 1981); and (3) the westward motion of Anatolian plate along the strikeslip North Anatolian Fault (NAF) (Pavlides \& Caputo, 2004). It is worth noting that the Greek region is the result of the intense collision of several microplates (Aegean, Anatolian and Apulian plate) that took place during the Alpine orogenesis since the Upper Cretaceous involving the subduction of Tethyan Ocean (van Hinsbergen et al., 2005). The volcanism of the area is located in the southern Aegean Sea, while the SAAVA comprises magma of calc-alkaline to shoshonitic suite and signs of crustal contamination (Pe-Piper \& Piper, 2006).

Based on the aforementioned complex tectonic setting and the prevailing geological formations, Mountrakis (1985, 2010) divided Greece into structural isopic zones, which from west to the east are:

(1) External Hellenides (EH): correspond to a neritic continental sea depositional environment and consist of the Parnassos, Gavrovo-Tripolis, Ionian and Paxos zones. It is worth mentioning that during the Middle-Upper Jurassic, the

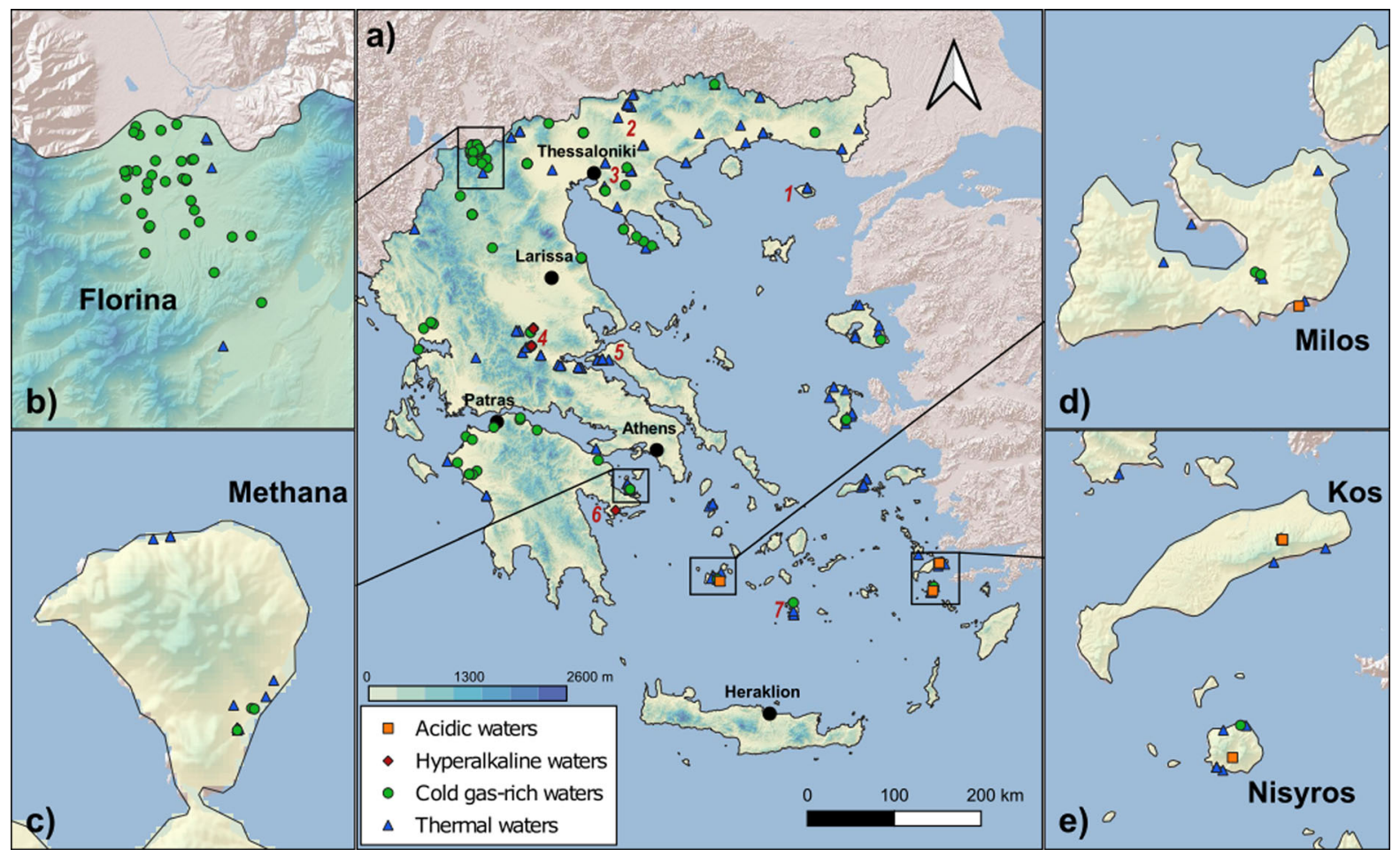

Fig. 1 Geographic distribution of the sampling sites. Insets are enlarged areas with high density of sampling sites. 1-Samothraki; 2Strimon Basin; 3-Migdonia Basin; 4-Othrys and Sperchios Basin; 5-Edipsos; 6-Argolida; 7-Santorini 
Ionian zone bearded an intracontinental basin with pelagic sediments. According to Doutsos et al. (2006), three major rift structures occurred during Mesozoic within the eastern margin of the Apulian continent that were reactivated in the Tertiary by forming intracontinental thrusts;

(2) Internal Hellenides (IH): express various environments and consist of the Pelagonian, Subpelagonian, Attico-cycladic, Circum-Rhodope and Vardar zones. Depending on their geographical position, they are characterised by obducted ophiolites and deep-sea sediments, neritic sediments, volcanoclastic and sea deposits or flysch. Neritic sediments prevail in the Pelagonian zone, which is considered to be a fragment of the Cimmerian microcontinent, while obducted ophiolites are the most characteristic lithological unit of the Subpelagonian zone. The latter is thought to be the continental slope of the Cimmerian continent towards the ocean, whose sedimentary remnants form the Pindos zone. Both zones consist of sea deposits and appear a progressively deepening sea towards the west. Similar to the Pelagonian, also the Attico-Cycladic zone is envisaged as a continental fragment with undergone neritic sedimentation. Alpidic lithostratigraphic succession bearing volcanoclastic and sea deposits ending up in deep-sea sediments westwards, and flysch are the lithologies characterising the Circum-Rhodope zone. The Vardar zone corresponds to the ocean of Tethys and is characterised by the presence of deep-sea sediments and obducted ophiolites;

(3) Hellenic Hinterland (HH): comprises a Precambrian-Silurian continental crust affected by Alpidic metamorphism and consists of the Rhodope and Serbomacedonian Massifs. Crystalline rocks are the main lithology for both zones, while neritic deposits and Late EoceneEarly Oligocene granitoid intrusions are present (Fig. 2a).

From a hydrogeological point of view, the outcropping lithologies in Greece can be subdivided in three major groups. The first is the porous aquifers comprising mainly Quaternary and Neogene sediments (Daskalaki \& Voudouris, 2008). These are mostly found within subsident extensional basins and cover about $30 \%$ of Greece. The second group comprises all karstic aquifers developed both in limestone of the sedimentary sequences and in marble within metamorphic complexes (Kallioras \& Marinos, 2015). The former crop out mainly in central, western and southern Greece and the latter in the northern part of the country, altogether covering about $35 \%$ of the whole area. The third group comprises all the remaining lithologies characterised by low permeability or being impermeable (flysch, clays, most metamorphic rocks, volcanites, ophiolites etc.).

Geology along with volcanism and tectonics favoured the existence of many thermal manifestations and anomalous degassing areas (Daskalopoulou et al., 2019a). The elevated heat flow resulted in numerous geothermal fields from low to high enthalpy (Andritsos et al., 2015; Fytikas \& Kolios, 1979), while the extensional tectonics (Fig. 2b) affected crustal thinning contributing to fault formation (Grigoriadis et al., 2016) and thus to the ascent of fluids. The elevated heat flow values noticed in the northern part of Greece were associated with the existence of a "first phase" volcanic arc (Fytikas et al., 1984; Vougioukalakis et al., 2004).

\section{Materials and methods}

The physico-chemical parameters (temperature, $\mathrm{pH}$, Eh and Electric Conductivity (EC)) were measured in situ with portable instruments. The total alkalinity was determined by titration with $0.1 \mathrm{~N} \mathrm{HCl}$ on unfiltered samples (expressed as $\mathrm{mgHCO}_{3}{ }^{-} / \mathrm{L}$ ). Water samples were filtered $(0.45 \mu \mathrm{m}$ MF-Millipore cellulose acetate filters) and stored in HDPE bottles, while the aliquot for determination of cation contents was acidified with ultrapure concentrated $\mathrm{HNO}_{3}$. Analyses of the water chemistry and the isotopic composition were carried out at the laboratories of Istituto Nazionale di Geofisica e Vulcanologia of Palermo (INGV-Pa).

Water chemistry was analysed using standard methods (APHA et al., 2005): major cations (Na, K, $\mathrm{Mg}, \mathrm{Ca})$ and major anions $\left(\mathrm{F}, \mathrm{Cl}, \mathrm{NO}_{3}, \mathrm{SO}_{4}\right.$ ) were determined by Ionic Chromatography (ICS-1100, Dionex), Si was determined by Inductively Coupled 

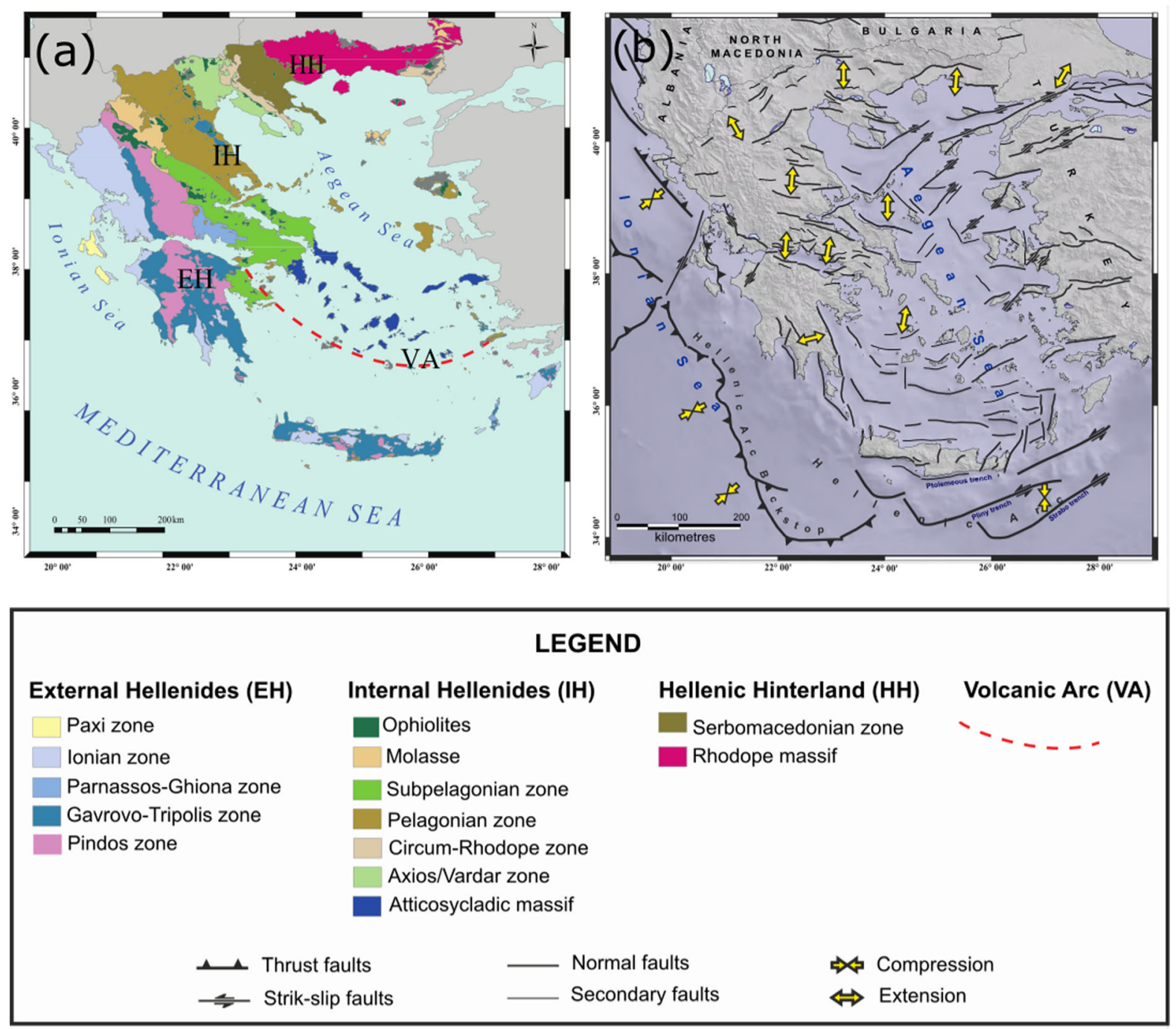

Fig. 2 Sketches illustrating the complex geodynamic situation of Greece. a Main geologic subdivisions (after Mountrakis, 1985): HH = Hellenic Hinterland; $\mathrm{IH}=$ Internal Hellenides;

Plasma-Optical Emission Spectrometry (ICP-OES; Yobin Ultima). Spectrophotometric methods were used for the determination of $\mathrm{NH}_{4}$ (Berthelot's reaction). Lithium was determined by Inductively Coupled Plasma-Mass Spectrometry (ICP-MS; Agilent) as well as $\mathrm{Mg}$ and $\mathrm{K}$, when found below detection limits in Ionic Chromatography. For all these analytical methodologies, precision was always better than $\pm 3 \%$. Speciation of waters and Saturation Index (SI) of main mineral phases for each water sample and the calculation of theoretical $p \mathrm{CO}_{2}$ for cold gas-rich
$\mathrm{EH}=$ External Hellenides; VA = Volcanic Arc; $\mathbf{b}$ map of the major tectonic structures and the current horizontal stress field main axes (Pavlides et al., 2010)

samples were obtained using the aqueous speciation PHREEQC software (Parkhurst \& Appelo, 1999).

Ionic balance (\%) was calculated with the formula:

$$
\left\{\left(\sum c a t+\sum a n\right) /\left[\left(\sum c a t-\sum a n\right) / 2\right]\right\} \times 100
$$

where cat are $\mathrm{Na}^{+}, \mathrm{K}^{+}, \mathrm{Mg}^{2+}$ and $\mathrm{Ca}^{2+}$ and an $\mathrm{Cl}^{-}$, $\mathrm{NO}_{3}{ }^{-}, \mathrm{SO}_{4}{ }^{2-}$ and total alkalinity all expressed as meq/ L.

TDS (Total Dissolved Solutes) expressed in $\mathrm{g} / \mathrm{L}$ is here intended as the sum of all major anions $\left(\mathrm{F}^{-}, \mathrm{Cl}^{-}\right.$, 
$\mathrm{NO}_{3}{ }^{-}, \mathrm{SO}_{4}{ }^{2-}$ and alkalinity as $\mathrm{HCO}_{3}{ }^{-}$) and cations $\left(\mathrm{Na}^{+}, \mathrm{K}^{+}, \mathrm{Mg}^{2+}\right.$ and $\left.\mathrm{Ca}^{2+}\right)$ plus $\mathrm{SiO}_{2}$.

The oxygen and hydrogen isotopic compositions of waters were determined by using, respectively, Analytical Precision AP 2003 and Finnigan MAT Delta Plus IR Mass Spectrometry on unfiltered samples. Results are expressed in delta notation (\%o) with respect to the international standard V-SMOW (Vienna Standard Mean Ocean Water). The uncertainties are $\pm 0.1 \%$ for $\delta^{18} \mathrm{O}$ and $\pm 1 \%$ for $\delta^{2} \mathrm{H}( \pm 1 \sigma)$.

Geothermometric estimations were obtained for some selected samples with the software Solute Geothermometers (SolGeo) that includes 35 geothermometric equations (Verma et al., 2008).

\section{Results}

Water geochemistry

The study area from where the waters were collected is characterised by a great diversity of lithologies and geodynamic environments, which is reflected in a large variety of measured physical-chemical parameters and chemical compositions (Supplementary Material-Table S1). Temperatures measured at spring outlet range from 6.5 to $98{ }^{\circ} \mathrm{C}$, while $\mathrm{pH}$ varies from 1.96 to 11.98 . It is worth noting that the great majority of the samples is delimited in $\mathrm{pH}$ values between 5.5 and 9 , while only few springs show either low to very low $\mathrm{pH}(<5)$ or very high $\mathrm{pH}$ values (>11). TDS concentrations range from 0.22 to $51 \mathrm{~g} /$ L. Based on the aforementioned parameters, the sampled waters were divided into cold $\left(<23{ }^{\circ} \mathrm{C}\right)$ and thermal $\left(>23{ }^{\circ} \mathrm{C}\right)$ waters, with the former being subdivided according to their $p \mathrm{CO}_{2}$ values and the latter according to their combined temperature values and TDS concentrations (low salinity, brackish and saline). Waters characterised by either very low or very high $\mathrm{pH}$ were considered as extra categories. The ionic balance of the cold and thermal waters is generally within the acceptable range of $\pm 10 \%$. Only three samples of each of these groups exceed such limit $3.2 \%$ of the cold and $1.8 \%$ of the thermal waters). On the contrary, both acid (80\%) and hyperalkaline $(16.7 \%)$ waters show often strong imbalances. These strong imbalances are not due, as normally considered, to analytical errors. They are mostly due to the presence of less common ionic species not considered in the calculation of the ionic balance. These are $\mathrm{OH}^{-}$in the case of hyperalkaline waters, $\mathrm{H}^{+}, \mathrm{NH}_{4}{ }^{+}$, ionic species of $\mathrm{Fe}, \mathrm{Mn}, \mathrm{Al}, \mathrm{Sr}, \mathrm{Ba}$ in the case of acidic waters, and ionic species of S(-II) and of organic molecules in the case of reduced waters. Almost all of the waters with strong imbalances here considered fall within one of these categories.

To better discriminate the different geochemical characteristics of the different groups, the data were plotted in a Langelier-Ludwig (1942) classification diagram (Fig. 3) and are described in detail below.

\section{Hyperalkaline waters}

The hyperalkaline waters are found in the Argolida ophiolites (Peloponnese) and the ophiolitic complex of Othrys (Central Greece). Samples of this group are characterised by very high $\mathrm{pH}$ values (11.17 and 11.98 ) and low salinity (TDS $<0.63 \mathrm{~g} / \mathrm{L}$ ). Temperature ranges from 17.4 to $27.7^{\circ} \mathrm{C}$, while alkalinity is mainly accounted by $\mathrm{OH}^{-}$ions. According to Barnes et al. (1967), they can be classified as $\mathrm{Ca}-\mathrm{OH}$ waters (Fig. 3a).

\section{Acidic waters}

The acidic waters are located in the islands of SAAVA, i.e. Kos (Kokkino Nero and Aspro Nero springs), Nisyros (Stefanos) and Milos (Paleochori). They are characterised by low $\mathrm{pH}$ values and a wide range of temperatures, which varies from 1.96 to 4.70 and from 13.9 to $98{ }^{\circ} \mathrm{C}$, respectively. It should be noted that the lowest $\mathrm{pH}$ (1.98) and the highest temperature $\left(98{ }^{\circ} \mathrm{C}\right)$ values were documented in one water sample of Stefanos crater (Nisyros). These samples are characterised by $\mathrm{CaMg}-\mathrm{SO}_{4}$ composition (Fig. 3b). Exception is Paleochori (Milos), which falls close to the Aegean seawater point and presents the highest TDS content $(51.2 \mathrm{~g} / \mathrm{L})$.

\section{Thermal waters}

Samples from this group were collected in hydrothermal fields located along the SAAVA and in continental basins. The diversity of the settings in which they were collected results in a wide range of temperature (from 23.2 to $95.5{ }^{\circ} \mathrm{C}$ ), $\mathrm{pH}$ (from 5.73 and 10.01) and salinity (from 0.3 to $43.2 \mathrm{~g} / \mathrm{L}$ ) values. Based on their 


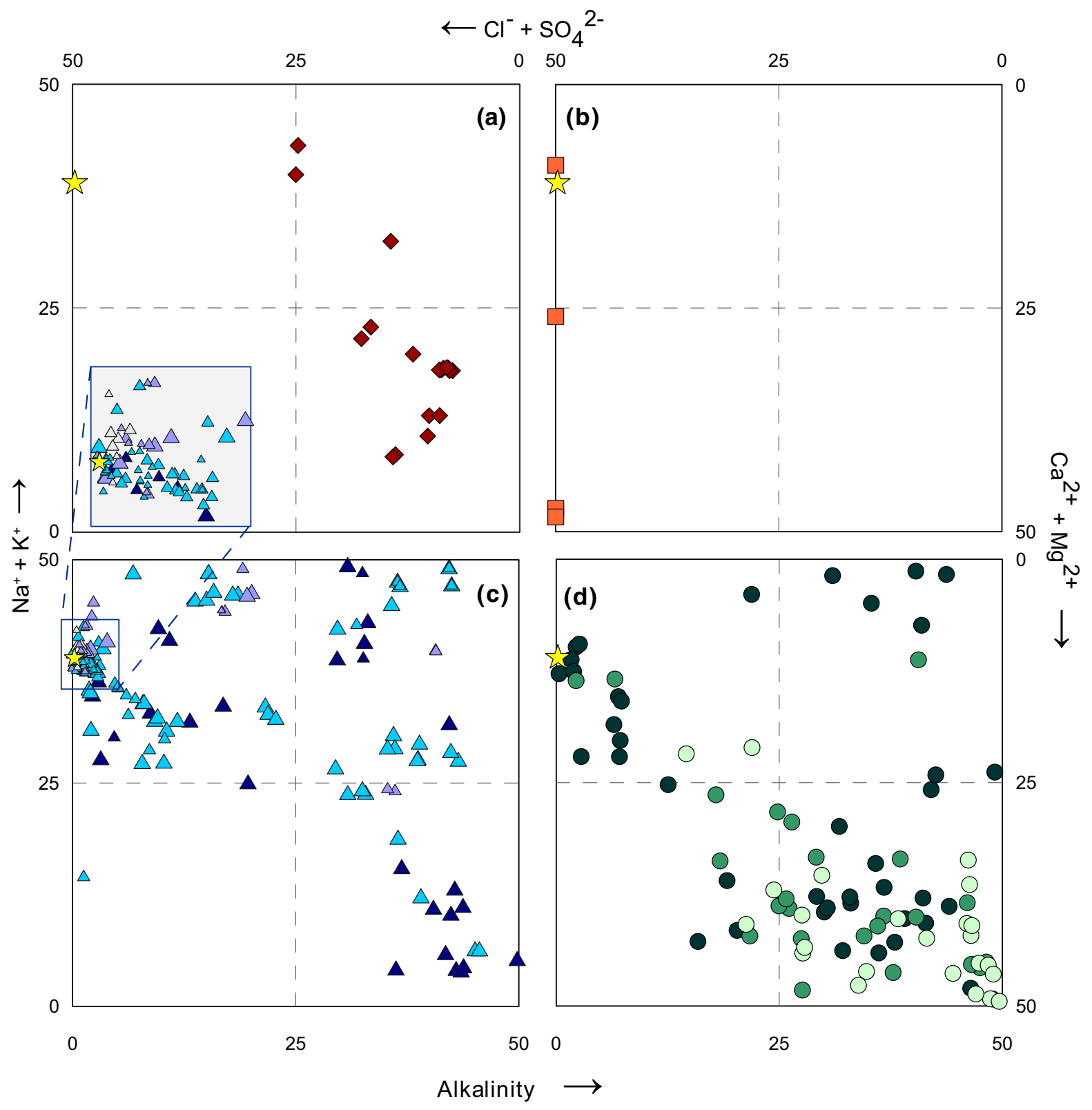

$\sum$ Seawater $\diamond$ Hyperalkaline waters $\square \quad$ Acidic waters

Cold gas-rich waters

- $\mathrm{pCO}_{2}<0.05 \bigcirc 0.05<\mathrm{pCO}_{2}<0.85 \bigcirc \quad \mathrm{pCO}_{2}>0.85$

Thermal waters

$\triangle$ TDS $<4 \mathrm{~g} / \mathrm{L} \quad \triangle \quad 4<$ TDS $(\mathrm{g} / \mathrm{L})<30 \quad \Delta \quad$ TDS $>30 \mathrm{~g} / \mathrm{L}$

$\triangle \quad \mathrm{T}<29^{\circ} \mathrm{C} \quad \triangle \quad 29<\mathrm{T}\left({ }^{\circ} \mathrm{C}\right)<48 \quad \triangle \quad 48<\mathrm{T}\left({ }^{\circ} \mathrm{C}\right)<75 \quad \triangle \quad \mathrm{T}>75^{\circ} \mathrm{C}$ 
4Fig. 3 Langelier-Ludwig classification diagram for a hyperalkaline, b acidic, $\mathbf{c}$ thermal and $\mathbf{d}$ cold gas-rich waters. The yellow star represents the composition of seawater

temperatures and TDS content, they are subdivided into different classes (Fig. 3c); this subdivision was made following the method of Sinclair (1974) to identify statistically different populations. Three populations were detected based on TDS, while four populations were identified considering the measured temperatures (Fig. 3c). According to their water compositions, they fall into three of the quadrants of the Langelier-Ludwig diagram (Fig. 3c): (1) CaMg$\mathrm{HCO}_{3}$ and (2) $\mathrm{Na}-\mathrm{HCO}_{3}$ water-types, which include mainly low salinity samples $(<4 \mathrm{~g} / \mathrm{L})$ and few intermediate salinity samples $(4<\mathrm{g} / \mathrm{L}<30)$, with temperatures almost below $48{ }^{\circ} \mathrm{C}$; (3) $\mathrm{NaCl}$ composition, which includes high temperature and salinity samples with compositions that fall mostly close to the seawater point.

\section{Cold gas-rich waters}

The cold water samples are characterised by the presence of high levels of geogenic gases found in free and/or dissolved phase. Temperature ranges from 8.8 to $23{ }^{\circ} \mathrm{C}$, pH between 5.20 and 8.72 , while salinity shows a wide spectrum of values in terms of TDS (from 0.31 to $30.1 \mathrm{~g} / \mathrm{L}$ ). Based on their $\mathrm{CO}_{2}$ content calculated as $p \mathrm{CO}_{2}$ using the speciation software PHREEQC (Parkhurst \& Appelo, 1999), they were divided into three groups; the groups were identified with the method proposed by Sinclair (1974). After plotting the samples in the Langelier-Ludwig diagram (Fig. 3d), it is noticed that the great majority of the waters with $p \mathrm{CO}_{2}>0.05$ falls in the $\mathrm{CaMg}-\mathrm{HCO}_{3}$ field, while samples characterised by low $p \mathrm{CO}_{2}$ $(<0.05)$ are scattered in all the sectors of the diagram.

\section{Isotopic composition}

The isotopic composition of the collected waters ranges from -2.7 to $+2.7 \%$ for $\delta^{18} \mathrm{O}$ and from 91 to $+12 \%$ for $\delta^{2} \mathrm{H}$. In the $\delta^{2} \mathrm{H}-\delta^{18} \mathrm{O}$ diagram (Fig. 4), the majority of the waters fall between the Global Meteoric Water Line (Craig, 1961: GMWL $\left.\delta^{2} \mathrm{H}=8 \times \delta^{18} \mathrm{O}+10\right)$ and the East Mediterranean Meteoric Water Line (Gat \& Carmi, 1971: EMMWL $\delta^{2} \mathrm{H}=8 \times \delta^{18} \mathrm{O}+22$ ). A Local Meteoric Water Line defined by Argiriou and Lykoudis (2006) (LMWL $\delta^{2} \mathrm{H}=7.24 \times \delta^{18} \mathrm{O}+8.2$ ) has been also plotted. Such LMWL has been obtained by the authors including all published isotope data on rainwater collected in Greece in the period from 1960 to 2003 (Argiriou \& Lykoudis, 2006). Hyperalkaline (Fig. 4a) and most of the thermal and cold waters (Fig. 4c, d) follow the LMWL of Greece. This suggests that the water samples have a meteoric origin, whereas acidic waters show a negative shift for $\delta^{18} \mathrm{O}$ (Fig. 4b).

Some thermal and cold waters are aligned with Aegean seawater point (Fig. 4c, d), indicating a mixing between the meteoric water and seawater. As marked in Fig. 4c and 4, many water samples show a positive $\delta^{18} \mathrm{O}$ shift. In the case of thermal waters this could indicate isotope exchange due to waterrock interaction at higher temperatures (Clayton et al., 1972), while in the case of cold waters it may be justified by evaporation processes.

The effect of seawater contamination can be observed in the $\delta^{2} \mathrm{H}$ versus $\mathrm{Cl}$ binary diagram (Fig. 5). Only few cold gas-rich waters show important seawater admixing (Fig. 5b), while this process is very widespread for the thermal waters (Fig. 5a). Some waters collected in Samothraki Island fall outside the rainwater-seawater mixing lines. For these, dissolution of Halite in Miocene evaporites have been invoked (Dotsika, 2012).

\section{Discussion}

Hyperalkaline waters

The ophiolitic sequences comprise widespread products derived from the hydration of ultramafic rocks, in which olivines and pyroxenes are altered to serpentine-group minerals (Evans et al., 2013). Typical features of waters circulating in serpentinised ultrabasic rocks are elevated $\mathrm{pH}$ values $(>10), \mathrm{Ca}-\mathrm{OH}$ composition with very low concentrations of $\mathrm{Mg}^{2+}$ and total dissolved carbon (TDC) mainly present as $\mathrm{CO}_{3}{ }^{2-}$ (Bruni et al., 2002). According to Barnes et al. (1967), two types of waters can be recognised in aquifers hosted in ophiolitic rocks: (1) $\mathrm{MgCaHCO}_{3}$ waters with $\mathrm{pH}$ generally $<10$ and (2) hyperalkaline $\mathrm{Ca}-\mathrm{OH}$ waters. The former represents the early stage of interaction between the ophiolites and meteoric 


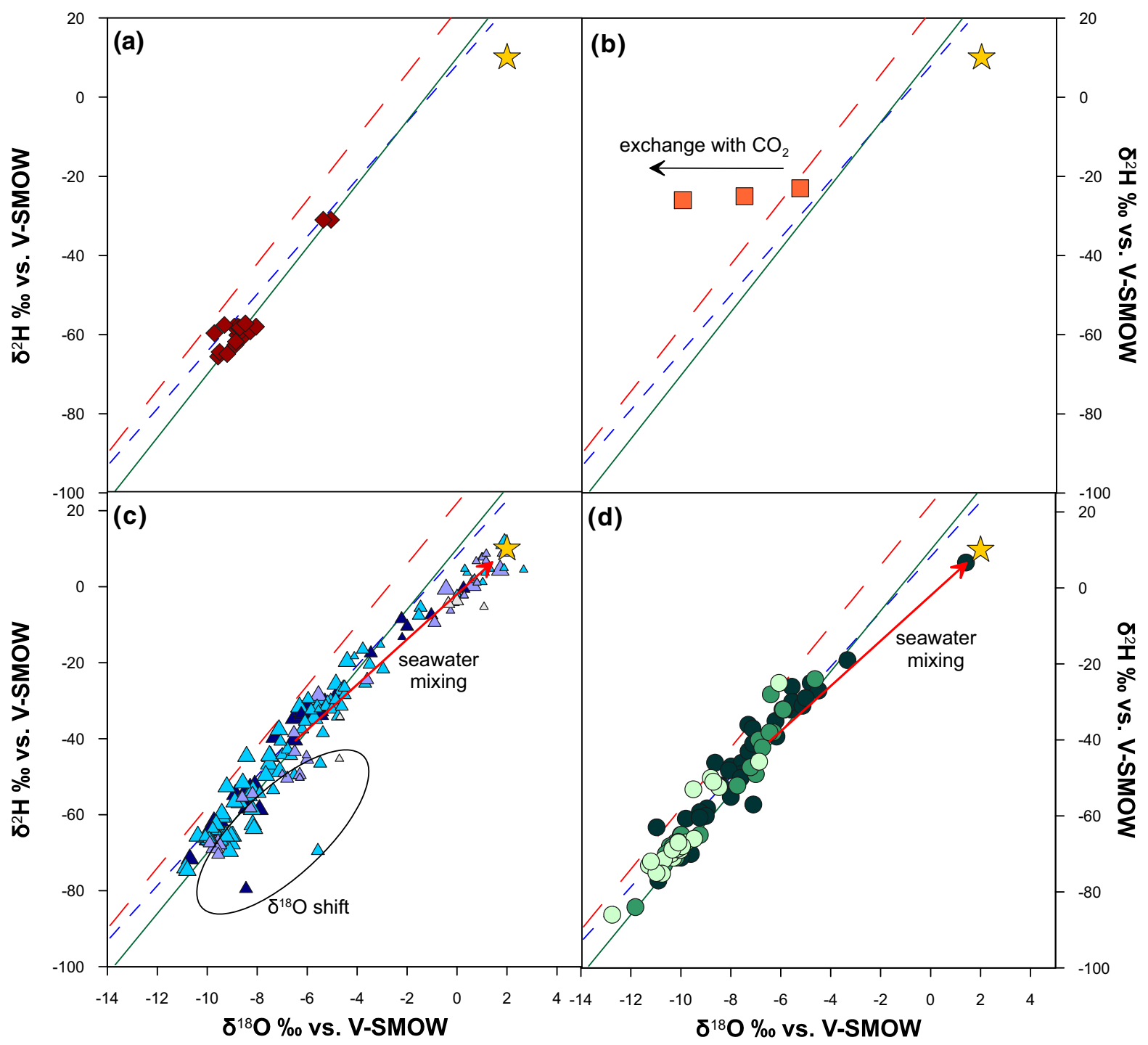

$\sum$ Seawater $\diamond$ Hyperalkaline waters $\square \quad$ Acidic waters

Cold gas-rich waters

- $\mathrm{pCO}_{2}<0.05 \bigcirc 0.05<\mathrm{pCO}_{2}<0.85 \bigcirc \quad \mathrm{pCO}_{2}>0.85$

Thermal waters

$\triangle$ TDS $<4 \mathrm{~g} / \mathrm{L} \quad \triangle \quad 4<\operatorname{TDS}(\mathrm{g} / \mathrm{L})<30 \quad \Delta \quad$ TDS $>30 \mathrm{~g} / \mathrm{L}$

$\triangle \quad \mathrm{T}<29^{\circ} \mathrm{C} \quad \triangle \quad 29<\mathrm{T}\left({ }^{\circ} \mathrm{C}\right)<48 \quad \triangle \quad 48<\mathrm{T}\left({ }^{\circ} \mathrm{C}\right)<75 \quad \triangle \quad \mathrm{T}>75^{\circ} \mathrm{C}$

- - - Greek Meteoric Water Line (Argiriou \& Lykoudis, 2005)

- Global Meteoric Water Line (Craig, 1961)

- - East Mediterrean Meteoric Water Line (Gat \& Carmi, 1971)

Fig. $4 \delta^{2} \mathrm{H}$ versus $\delta^{18} \mathrm{O}$ binary diagrams for the sampled waters 

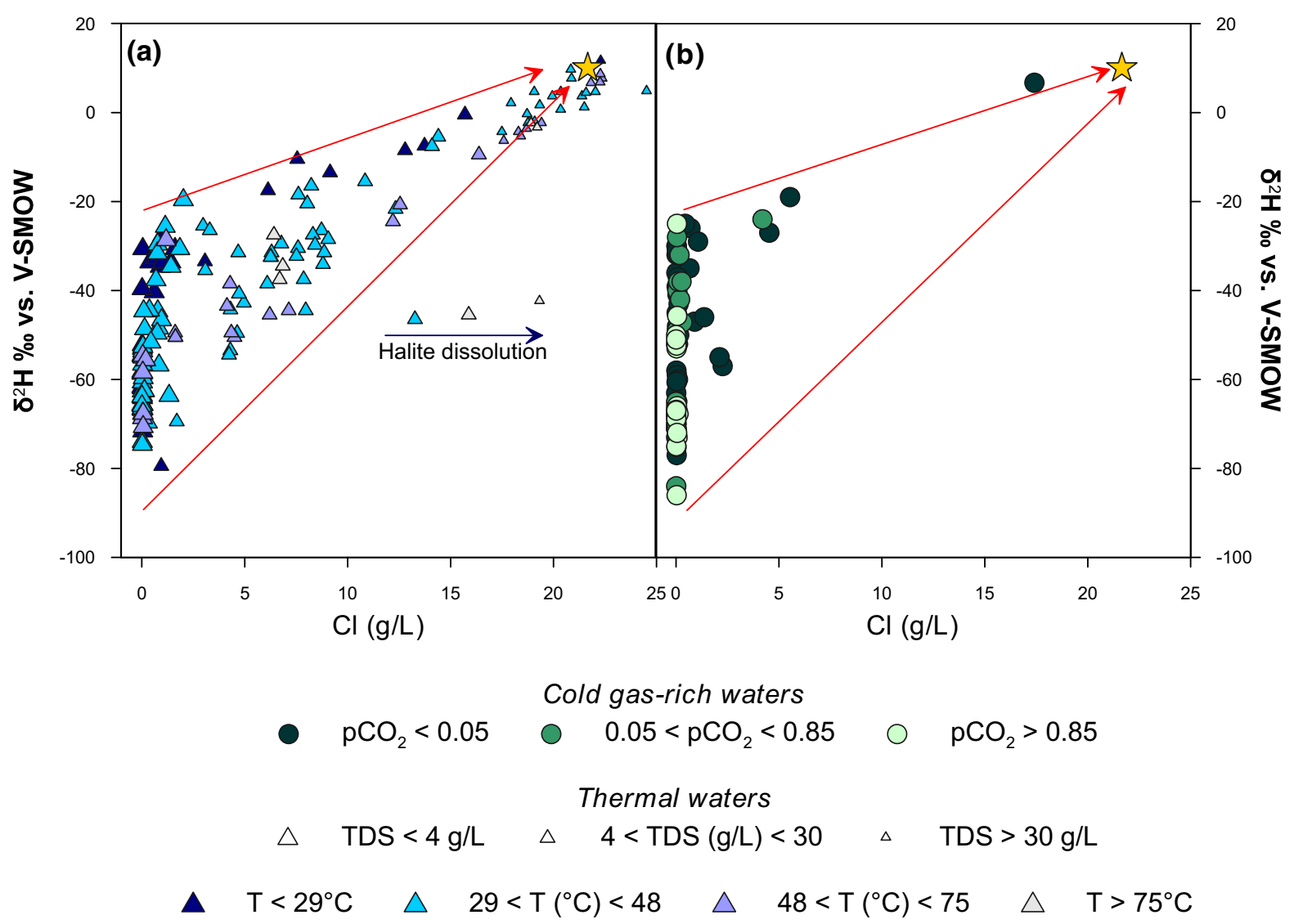

Fig. $5 \delta^{2} \mathrm{H}$ versus chloride binary diagrams for the sampled waters. Red arrows show mixing lines between the highest and lowest average isotopic value of rainwater measured in Greece (Argiriou \& Lykoudis, 2006)

waters into shallow aquifers (Cipolli et al., 2004), while the latter represents its evolution in deep serpentinised ultramafic aquifers under reducing environment (Bruni et al., 2002). Samples of Argolida ophiolites (Peloponnese) are represented by the Agioi Anargyroi Springs, which are characterised by enhanced $\mathrm{pH}$ values (up to 11.98) and $\mathrm{Ca}-\mathrm{OH}$ composition (D'Alessandro et al. 2018). On the other hand, samples of Othrys (Central Greece) are characterised by many hyperalkaline springs $(\mathrm{pH}>11$; Ekkara and Archani), which are classified as $\mathrm{Ca}-$ OH-type waters (D'Alessandro et al. 2014; Li Vigni et al., 2021).

Acidic waters

Samples of this group present characteristics similar to acidic waters as described in Giggenbach (1988). These waters can be distinguished in three different subgroups each one belonging to a different island of the SAAVA.

Samples collected at Kos Island are characterised by acid sulfate composition, likely related to the addition of $\mathrm{CO}_{2}$ - and $\mathrm{H}_{2} \mathrm{~S}$-rich hydrothermal gases to groundwater (Giggenbach, 1988), and exhibit high concentrations of $\mathrm{Ca}^{2+}$ (up to $508 \mathrm{mg} / \mathrm{L}$ ) and $\mathrm{SO}_{4}{ }^{2-}$ (up to $2,774 \mathrm{mg} / \mathrm{L}$ ). These springs are found within an area of strong geogenic soil degassing (Daskalopoulou et al., 2019b). The abundant deep hydrothermal $\mathrm{H}_{2} \mathrm{~S}$ gas dissolves in the shallow aquifer and is converted into $\mathrm{H}_{2} \mathrm{SO}_{4}$ by oxidation with atmospheric oxygen dissolved in the meteoric recharge (Nordstrom et al., 2009). Such process increases the sulfate content and lowers the $\mathrm{pH}$ of the water. The isotopic composition shows a negative shift of $\delta^{18} \mathrm{O}$ (up to about 5\%o units) with respect to the local meteoric water line (Fig. 4b). The effect can be the result of isotope exchange with 
$\mathrm{CO}_{2}$ (Karolytè et al., 2017) at low temperature favoured by the high gas/water ratio.

The sample of Stefanos crater (Nisyros) is characterised by an elevated temperature $\left(98{ }^{\circ} \mathrm{C}\right)$, very low $\mathrm{pH}$ value (1.98) and an acidic sulfate composition. It was collected in a boiling pool of the hydrothermal explosion crater of Stefanos within the Lakki caldera. The crater is characterised by strong fumarolic activity (Marini \& Fiebig, 2005), mainly concentrated along the rim. An area of about $1000 \mathrm{~m}^{2}$ with many tens of boiling pools is present in the middle of the crater, the water of which probably results from the mixing of condensing fumarolic vapour and meteoric-derived shallow groundwater. In the summer dry period, the pools' level falls to about $1 \mathrm{~m}$ depth, while in winter, after heavy rainfall, the entire bottom of the crater can be covered by rainwater, forming an ephemeral lake. The collected sample has the typical steam-heated water composition (Nordstrom et al., 2009) with high concentrations of $\mathrm{SO}_{4}{ }^{2-}$, low $\mathrm{pH}$ and high temperature. Sulfate is almost the only anion balanced by a lot of cations including $\mathrm{Fe}, \mathrm{Al}$ and $\mathrm{NH}_{4}{ }^{+}$that have concentrations comparable to the major cations.

The Paleochori sample was collected at a small cave on the western end of Paleochori Beach (Milos) and is characterised by high temperature $\left(75^{\circ} \mathrm{C}\right)$ and $\mathrm{NaCl}$ water type. The water of the spring comes out with gas bubbles from rocky debris and gets mixed with seawater, when the sea is rough. Its chemical composition is similar to marine water, indicating that, even if the sea is calm, contamination by seawater occurs within the shallowest part of the hydrological circuit. The area is characterised by widespread degassing both onshore as diffuse degassing from the beach and underwater as bubbling hot water (up to $120{ }^{\circ} \mathrm{C}$ ) springs (Daskalopoulou et al., 2018b).

\section{Cold gas-rich waters}

As mentioned in Par. 4.3, cold mineral waters have been subdivided into three statistically different populations based on their $p \mathrm{CO}_{2}(<0.05$-from 0.05 to 0.85 and $>0.85 \mathrm{~atm}$ ), with the lowest value almost corresponding to the highest limit of organic derived soil $\mathrm{CO}_{2}$ contribution to groundwater (Chiodini et al., 1995). Therefore, values above this limit indicate a geogenic $\mathrm{CO}_{2}$ contribution. Recent studies (Daskalopoulou et al., 2018a, 2019a) evidenced that Greece, being a geodynamically active region, is a territory of extensive geogenic degassing. Most of the degassing activity in Greece is associated to thermal anomalies of variable intensity, but especially in Northern Greece the two phenomena are sometimes unrelated. In this area, several cold $\mathrm{CO}_{2}$-rich mineral waters are known and many of them are appreciated as natural soda waters suitable for human consumption, with some of them being distributed in the whole country (i.e. Doumbia, Souroti and Xino Nero).

Most of the $\mathrm{CO}_{2}$-rich groundwater samples were collected in Florina Basin. This is one of the intramontane basins within the Hellenide Orogen, formed by the extensional tectonic regime of the area starting from the Late Miocene (Pavlides \& Mountrakis, 1987). The thick and impermeable sedimentary sequence of Florina basin favoured the existence of many $\mathrm{CO}_{2}$ reservoirs (Karakatsanis et al., 2007). Some of these are industrially exploited by the Air Liquide Greece Company for production of dry ice and filling of pressurised gas bottles. The estimated industrial $\mathrm{CO}_{2}$ extraction is $\sim 30,000 \mathrm{t} / \mathrm{a}$ (Pearce, 2004). However, these reservoirs are leaky, thus $\mathrm{CO}_{2}$ rises up, mainly through faults, reaching directly the atmosphere or being dissolved in great quantities in the shallow unconfined aquifers. The water extracted from many of the shallow wells $(<100 \mathrm{~m})$ dug or drilled in these aquifers separates a free gas phase due to the high concentration in $\mathrm{CO}_{2}$ (D'Alessandro et al., 2011).

The equilibrium of carbonate species is regulated mainly by sources and sinks within the hydrologic circuit. The main sources are the deep-derived geogenic $\mathrm{CO}_{2}$ dissolution and/or the dissolution of carbonate rock of the aquifers. Losses depend mainly on $\mathrm{CO}_{2}$ exsolution due to the separation of a free gas phase as water pressure within the aquifer decreases in the shallower levels and/or on precipitation of carbonate minerals due to oversaturation. The majority of samples with high $p \mathrm{CO}_{2}$ are characterised by $\mathrm{Ca}-$ $\mathrm{HCO}_{3}$ composition. The dissolution of $\mathrm{CO}_{2}$ strongly dominates the chemical evolution of these waters increasing their aggressiveness with respect to the aquifer's rocks.

As a consequence, bicarbonate represents generally more than $70 \%$ by weight of their TDS, and $\mathrm{pH}$ is slightly acidic (5.2-6.9). Due to the high $p \mathrm{CO}_{2}$ values (Fig. 6a), in this group of waters, saturation or oversaturation in carbonate minerals (Calcite, Aragonite or Dolomite) is rarely achieved (Fig. 6b). In the intermediate $\mathrm{pCO}_{2}$ population, only few samples 


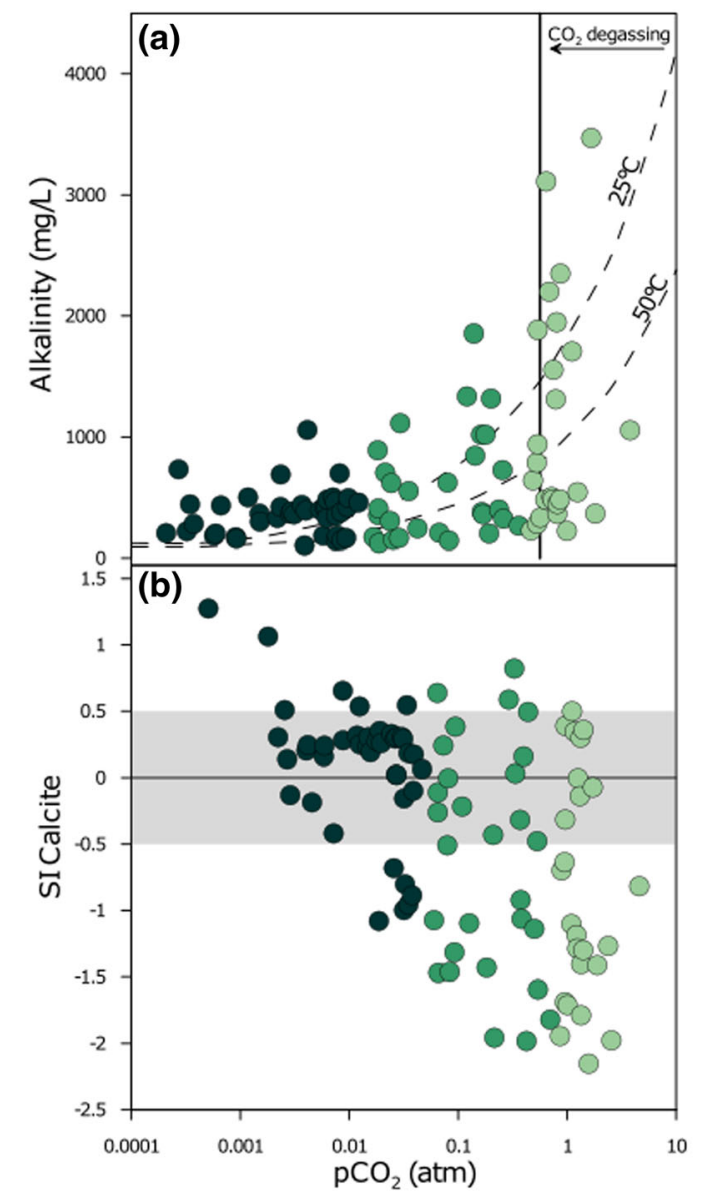

\section{Cold gas-rich waters \\ - $\mathrm{pCO}_{2}<0.05-0.05<\mathrm{pCO} 2<0.85 \bigcirc \mathrm{pCO}_{2}>0.85$}

Fig. $6 \mathrm{CO}_{2}$ partial pressure versus alkalinity (a) and versus calcite saturation index (b) of the cold gas-rich waters. Dashed lines in (a) are concentrations of alkalinity (expressed as $\mathrm{mg} / \mathrm{L}$ of $\mathrm{HCO}_{3}{ }^{-}$) at the given $\mathrm{CO}_{2}$ partial pressure at 25 and $50{ }^{\circ} \mathrm{C}$. The grey shaded area in $(\mathbf{b})$ comprises values $( \pm 0.5)$ considered at saturation for the given solid phase

result oversaturated (Fig. 6b). Equilibrium with carbonate minerals is rarely attained in the waters with $p \mathrm{CO}_{2}>0.05 \mathrm{~atm}$ indicating that carbonate dissolution in these waters is not so important as the $\mathrm{CO}_{2}$ dissolution. On the contrary, many of the waters with $p \mathrm{CO}_{2}<0.05 \mathrm{~atm}$ are close to equilibrium with the main carbonate minerals. These waters are from sedimentary areas, where the presence of carbonate rocks in their aquifers is ascertained or probable and these rocks control the equilibrium of the dissolved carbonate species. In these waters, the dissolved and/ or, if present, the free gas phases are dominated by
$\mathrm{CH}_{4}$ or $\mathrm{N}_{2}$ (Daskalopoulou et al., 2018a, 2019a). Geographically, these waters are mainly distributed in the western part of Greece, where $\mathrm{CO}_{2}$ degassing is trivial and hydrocarbon-rich areas are present (Daskalopoulou et al., 2018a, 2019a).

Only few cold water samples have a $\mathrm{NaCl}$ composition, indicating a significant seawater contamination of the aquifers. These are located along the coastlines of continental Greece or on islands. Despite their moderately low temperatures $\left(19.4-20.7^{\circ} \mathrm{C}\right)$ that classify them cold, they have been used in the past as spas and are therefore included in the present inventory. In the $\mathrm{Na}$ versus $\mathrm{Cl}$ binary diagram (Fig. 7a), they fall along the seawater mixing line. Almost all of the low salinity waters are enriched in $\mathrm{Na}$ with respect to the $\mathrm{Na} / \mathrm{Cl}$ ratio in seawater due to water-rock interaction processes within their aquifers.

Very few water samples plot along the $1 / 1$ ratio line in the $\mathrm{Ca}^{2+}$ versus $\mathrm{SO}_{4}{ }^{2-}$ binary plot (Fig. 7b) suggesting only a sporadic influence of Ca-sulfate minerals dissolution. Most of the waters are strongly enriched in $\mathrm{Ca}^{2+}$ confirming the strong influence of Ca-carbonate dissolution. But as we will see for the thermal waters, $\mathrm{Ca}^{2+}$ enrichment may occur also in the case of Ca-sulfate minerals dissolution, when the thermodynamic conditions are favourable to sulfate reduction to sulfide. This is probably the case of most waters collected in the western part of Greece, where Triassic evaporitic gypsum is often found in the sedimentary sequences of the area (Rigakis \& Karakitsios, 1998). Thermochemical sulfate reduction can be sustained by the presence of hydrocarbons in the same area (Palacas et al., 1986), which promote the sulfide formation (Machel, 2001).

Most of the cold water samples are more or less aligned along the $1 / 1$ ratio in a $\mathrm{Ca}^{2+}+\mathrm{Mg}^{2+}$ versus alkalinity binary diagram (Fig. 7c) indicating a strong influence of the congruent dissolution of carbonate minerals within their aquifers. Only in few cases the mixing of seawater can be invoked to explain a $\mathrm{Ca}^{2+}$ $+\mathrm{Mg}^{2+}$ excess with respect to the $1 / 1$ ratio line. On the contrary, most of the deviations from this line may be due to oversaturation of some carbonate species. In this case, the precipitation of a solid phase will virtually enrich either the cations $\left(\mathrm{Ca}^{2+}\right.$ and $\left.\mathrm{Mg}^{2+}\right)$ or the anion $\left(\mathrm{HCO}_{3}{ }^{-}\right)$depending on which one is in excess with respect to the $1 / 1$ equivalent ratio. Calcium excess may be favoured by the presence and dissolution of Ca-sulfate minerals, while 
Fig. 7 Binary correlation plots for the cold gas-rich waters. a $\mathrm{Na}^{+}$versus $\mathrm{Cl}^{-}$; b $\mathrm{Ca}^{2+}$ versus $\mathrm{SO}_{4}{ }^{2-}$; c $\mathrm{Ca}^{2+}+\mathrm{Mg}^{2+}$ versus alkalinity. Dashed line seawater mixing line, continuous line $1 / 1$ ratio
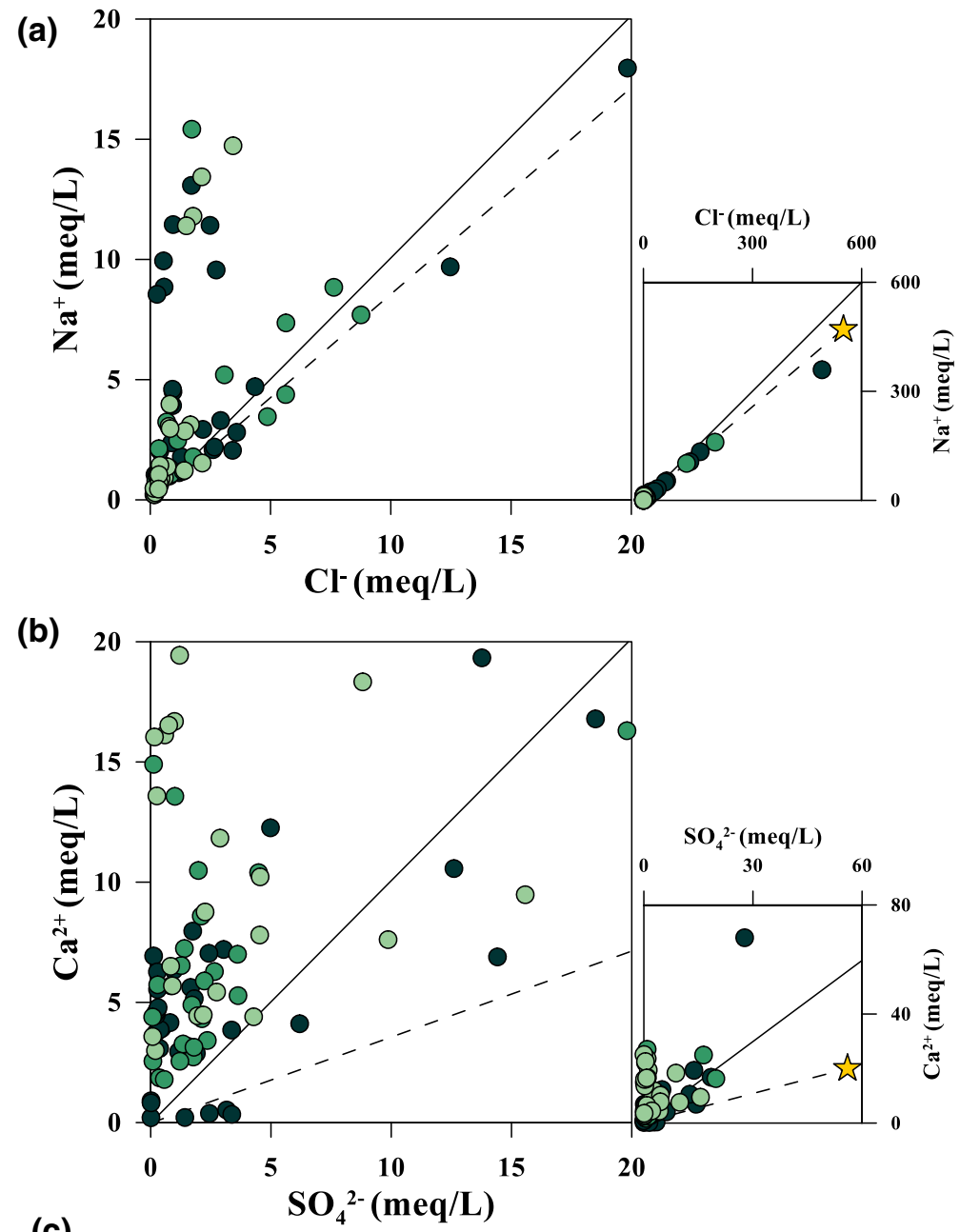

(c)

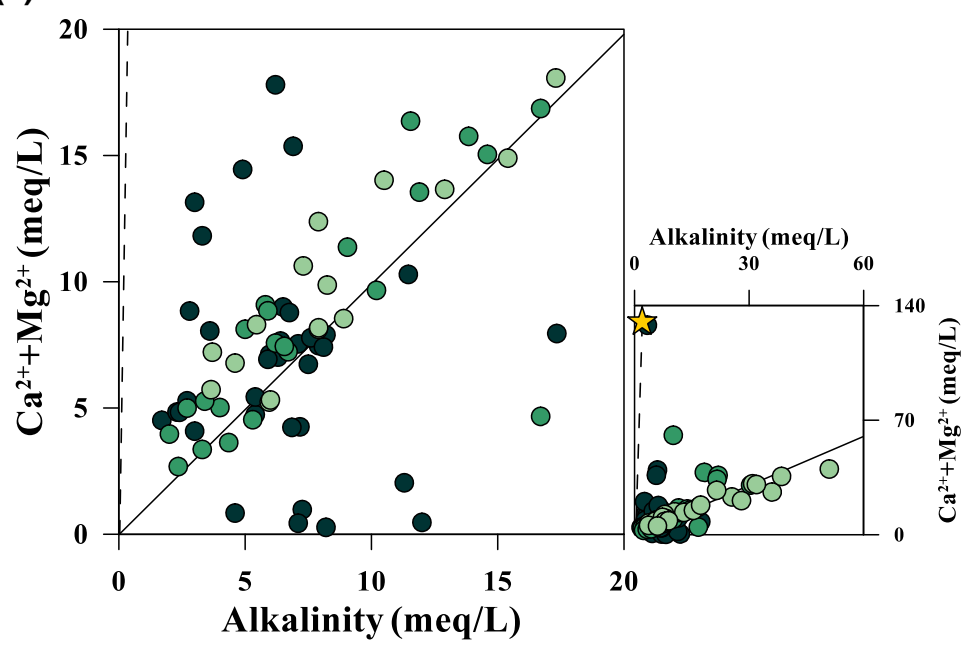

Cold gas-rich waters

- $\mathrm{pCO}_{2}<0.05 \bigcirc 0.05<\mathrm{pCO}_{2}<0.85 \bigcirc \bigcirc \quad \mathrm{pCO}_{2}>0.85$ 
bicarbonate excess may derive from the dissolution of abundant geogenic $\mathrm{CO}_{2}$. The latter process may justify the formation of the alkaline-bicarbonate waters (Fig. 3d).

\section{Thermal waters}

Geologically young regions like the Alpine orogen show a high variability in heat flow with respect to older cratonic areas (Pollack et al., 1993). Greece, which belongs to the Alpine orogen, makes no exception. In the preliminary map of Fytikas and Kolios (1979), heat flow shows values that range from $<30$ to $>120 \mathrm{~mW} / \mathrm{m}^{2}$ (Fig. 10b). Values above the average continental heat flow $(65 \mathrm{~mW} /$ $\mathrm{m}^{2}$-Pollack et al., 1993) are considered as positive anomalies. Looking at the map of Fytikas and Kolios (1979), these anomalous values are mainly found in areas with active or recent $(<10 \mathrm{Ma})$ intrusive or effusive magmatism (Pe-Piper \& Piper, 2002). These areas are also those with the thinnest crust (Grigoriadis et al., 2016) and subject to active extensional tectonics (Pavlides et al., 2010 (Fig. 2b). The highest heat flow anomalies are recorded along the SAAVA. Signs of the increased heat flow are thermal springs and thermal groundwater tapped by drillings. Therefore, it is not a surprise to find the hottest thermal waters in the areas of increased heat flow (Fig. 10b). These thermal waters, together with fumaroles and steaming grounds, are the surface expressions of active geothermal systems. Geothermal exploration proved that two of them, located in the active volcanic systems of Milos and Nisyros, are two-phase high-enthalpy fields suitable for electricity production. Explorative drillings tapped geothermal fluids with temperatures up to 320 and $340{ }^{\circ} \mathrm{C}$, respectively (Chiodini et al., 1993; Liakopoulos et al., 1991). Geothermal energy was exploited for a period by a power plant at Milos until it was stopped by the protests of the inhabitants complaining for the $\mathrm{H}_{2} \mathrm{~S}$ released by the extracted geothermal fluids (D'Alessandro et al., 2009). The remaining explored geothermal reservoirs can be defined as hot-water systems (Kaya et al., 2011).

Many of the geothermal systems are found on islands or are on the coast of continental Greece (Fig. 1). Therefore, seawater plays a major role in determining the composition of the waters released by these systems. This can be evidenced both in their chemical composition with $\mathrm{Na} / \mathrm{Cl}$ ratios very close to that of seawater (Fig. 8a) and in their isotopic composition (Figs. 4 and 5) nicely evidencing a mixing between meteoric and sea water. From these diagrams, it cannot be deduced if seawater acts as a contaminant in the shallowest part of the hydrologic circuit or if it represents a main feeder of the geothermal reservoir. For the high-enthalpy systems of Milos and Nisyros, a strong contribution of seawater to the reservoir has been ascertained from the analyses of the fluids sampled from the explorative boreholes (Chiodini et al., 1993; Liakopoulos et al., 1991). However, a clue of a seawater contribution in several other reservoirs is the fact that many of the samples plotting close to the seawater point are those with the highest temperatures (Figs. 3, 4 and 5). As we will see in par. 5.4.1, these are often waters falling in the field of the partially equilibrated waters in the Giggenbach triangular plot (Fig. 9b).

Many water samples show a very high $\mathrm{Na} / \mathrm{Cl}$ ratio (Fig. 8a). Almost all come from three graben areas filled by postorogenic sediments mainly deriving from the dismantling of the metamorphic rocks bordering these grabens. These are the Sperchios, Strimon and Migdonia basins. The faults bordering the grabens favoured the formation of hydrothermal systems, while the ubiquitous presence of Na-rich minerals (e.g. albite) in the metamorphic rocks and in the sediments from them derived allowed the formation of Na-rich waters (Meyback, 1987). For the same reasons, similar conclusions may be drawn also for the cold gas-rich waters collected in the Florina basin and some artesian wells along the northern and western coast of Peloponnese (Fig. 7a).

As seen before for the cold waters, also in the case of thermal waters very few samples fall along the line representative of the dissolution of Ca-sulfate minerals (Fig. 8b). The great majority of the waters are enriched in $\mathrm{Ca}^{2+}$ that is mostly explainable by the release of this cation by high-temperature water-rock interaction processes. But the sulfate deficit may be, at least partially, explained by the reduction to sulfur and sulfide. While in the high-temperature systems such reduction involves only inorganic reactions in the case of lower temperatures microbiological mediated sulfur reduction is also involved, sometimes presupposing the presence of thermophile microorganisms (Brombach et al., 2003; Chiodini et al., 1998; Gilhooly et al., 2014). The rapidly changing physico-chemical conditions in the shallowest part of the hydrothermal 
Fig. 8 Binary correlation plots for the thermal waters. a $\mathrm{Na}^{+}$versus $\mathrm{Cl}^{-}$; $\mathbf{b} \mathrm{Ca}^{2+}$ versus $\mathrm{SO}_{4}{ }^{2-}$;

$\mathrm{c} \mathrm{Ca}^{2+}+\mathrm{Mg}^{2+}$ versus alkalinity. Dashed line seawater mixing line, continuous line $1 / 1$ ratio (a)

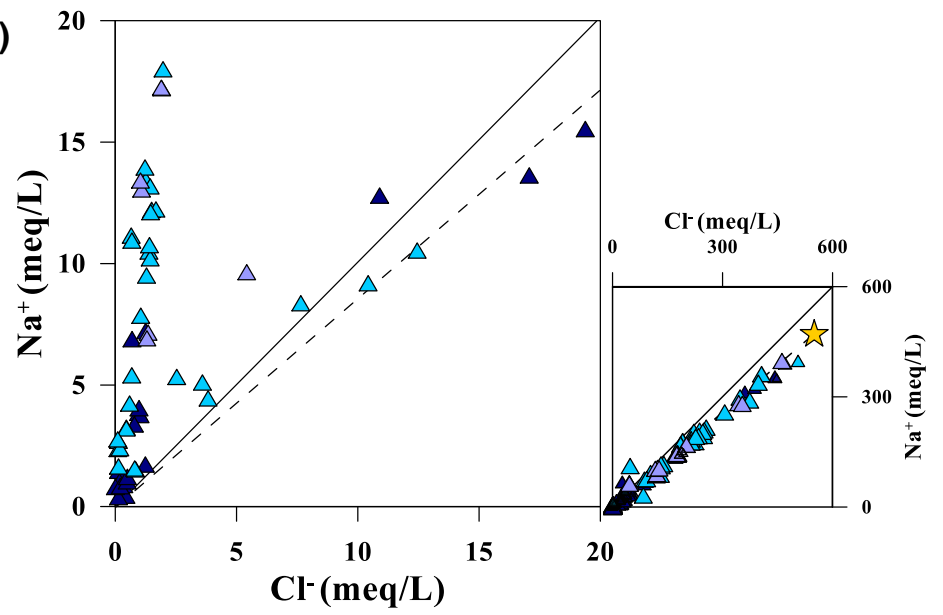

(b)

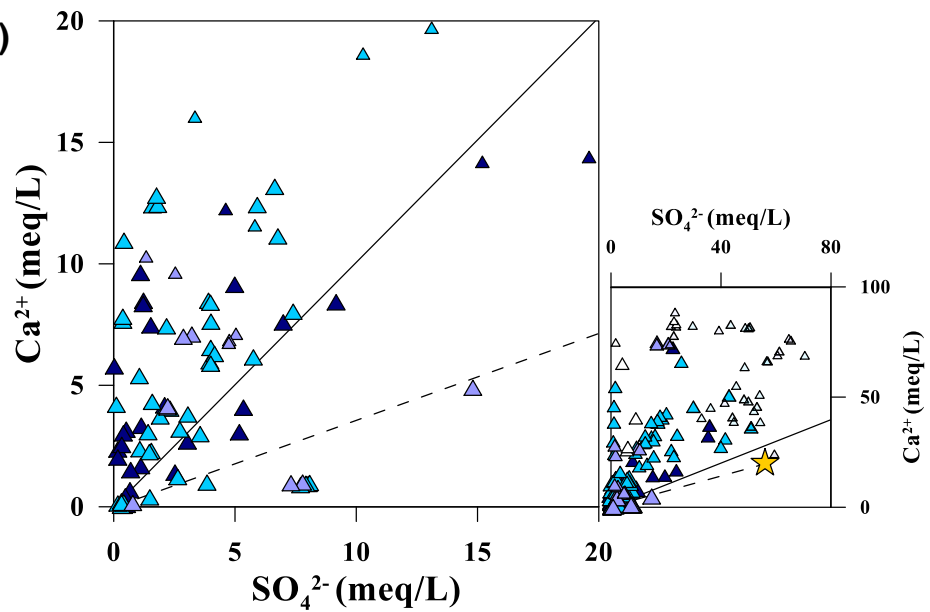

(c)

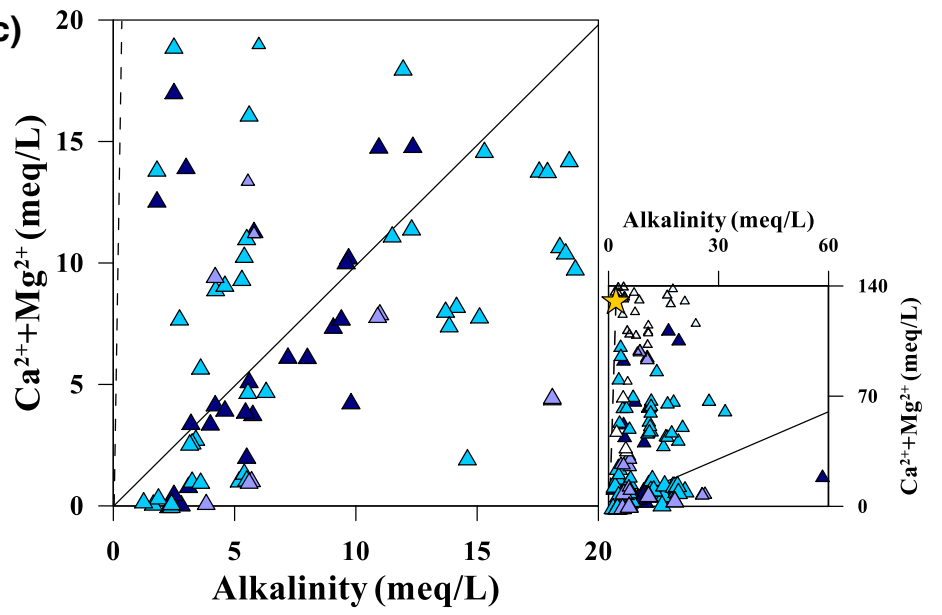

Thermal waters

$\triangle \mathrm{T}<29^{\circ} \mathrm{C} \triangle \quad \triangle \quad 29<\mathrm{T}\left({ }^{\circ} \mathrm{C}\right)<48 \quad \triangle \quad 48<\mathrm{T}\left({ }^{\circ} \mathrm{C}\right)<75 \quad \triangle \quad \mathrm{T}>75^{\circ} \mathrm{C}$ 


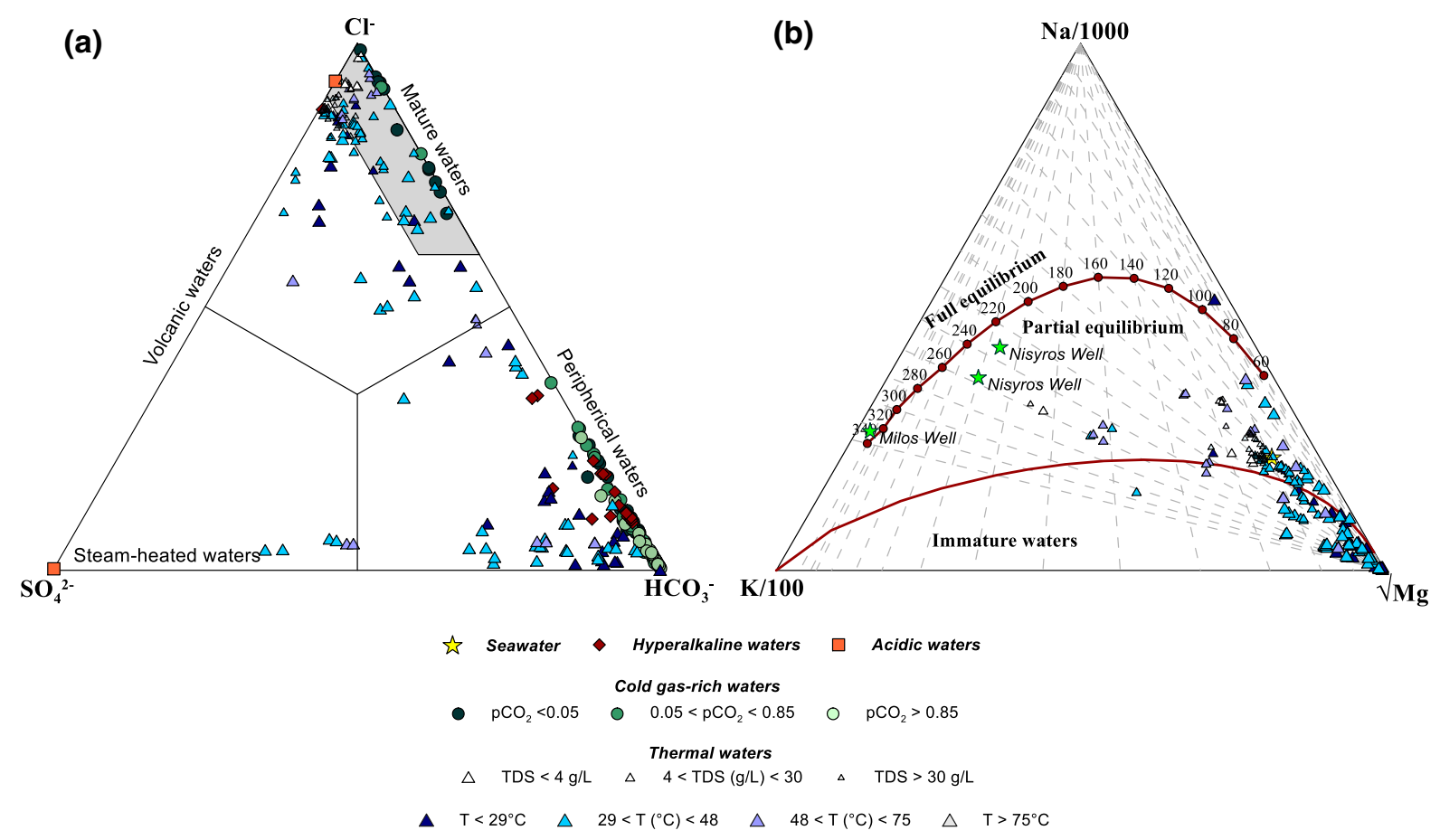

Fig. 9 Triangular diagrams of a Cl- $\mathrm{SO}_{4}-\mathrm{HCO}_{3}$ (Giggenbach, 1991) and b $\mathrm{Na}-\mathrm{K}-\mathrm{Mg}$ (Giggenbach, 1988)

circuit induces rapid changes in the oxidation state of sulfur further complicating the picture in a complex interaction between biotic and abiotic influences on the sulfur cycle (Gilhooly et al., 2014; Marini et al., 2002). This may affect also on other dissolved species like for example methane. Strong isotope fractionation of this gas has been, in fact, attributed to anaerobic methane oxidation involving the microbial reduction of sulfate as electron donor (Daskalopoulou et al., 2018a).

Spas in western Greece are fed by hypothermal or even cold springs. They are generally heated for balneotherapy and considered healthy mainly for their mineral content. Most of them are rich in dissolved sulfide and the exsolved $\mathrm{H}_{2} \mathrm{~S}$ can be distinctly smelled. This region corresponds to the thick organic-rich sedimentary sequences of the External Hellenides (Fig. 2a), which are considered the most favourable areas in Greece for hydrocarbon generation (Palacas et al., 1986; Rigakis \& Karakitsios, 1998). Thus, in the sampled waters methane is generally the dominant gas both in the dissolved and the free gas phase (Daskalopoulou et al., 2018a, 2019a). This is the Greek region with the greatest crustal thickness and hence the conditions are unfavourable to the uprise of gases and heat from the mantle. Therefore, this area is not prone to the formation of geothermal systems and the slight thermalisation of the waters is mostly the consequence of the deep circulation within regional fault systems. The stratigraphic sequences of the External Hellenides comprise often gypsum-rich Triassic evaporites (Rigakis \& Karakitsios, 1998). The presence of sulfates and hydrocarbons favours the formation of $\mathrm{H}_{2} \mathrm{~S}$ through either Microbial (MSR) or Thermochemical (TSR) Sulfate Reduction (Machel, 2001). The presence of $\mathrm{H}_{2} \mathrm{~S}$ in the water samples in western Greece is mainly related to these processes rather than being produced in active geothermal systems.

Finally, the $\mathrm{Ca}^{2+}+\mathrm{Mg}^{2+}$ versus alkalinity binary diagram (Fig. 8c) shows that the interaction with carbonate minerals is negligible and evidences two main processes affecting these waters: mixing with seawater and dissolution of geogenic $\mathrm{CO}_{2}$.

\section{Geothermometry}

The ternary diagram $\mathrm{Cl}-\mathrm{SO}_{4}-\mathrm{HCO}_{3}$ (Giggenbach, 1991) is used to examine the maturity of waters. Specifically, mature waters are characterised by high 
$\mathrm{Cl}$ content that originates from a deep-hot geothermal system, while $\mathrm{SO}_{4}$-type waters usually derive from steam-heated water influenced either by volcanic steam bearing high-temperature $\mathrm{HCl}$ or by geothermal steam bearing low-temperature $\mathrm{H}_{2} \mathrm{~S}$ (Dolgorjav, 2009; Rezaei et al., 2018). On the other hand, alkaline waters are typically related to samples of meteoric origin. In the Hellenic territory, hyperalkaline waters, as well as the great majority of cold waters and some thermal waters fall in the $\mathrm{HCO}_{3}$ field, indicating processes of mixing with the near-surface groundwater during their ascent to the surface (Singh et al., 2015) (Fig. 9a). Enrichment in $\mathrm{SO}_{4}$ is present in some thermal (Nymfopetra, Nea Apolonia $(1,3,4)$ ) waters. These samples (thermal) present low $\mathrm{Cl}$ content, high $\mathrm{Na}$ concentration and are characterised by calcite precipitation indicated by the presence of travertines in these areas. The fumarolic samples of Stefanos and Paleochori are plot in the $\mathrm{SO}_{4}-\mathrm{Cl}$ axis, which is typical of volcanic waters, highlighting the impact of the volcanic activity on the samples. Many thermal gases fall in the field of mature waters. These samples may be considered as samples not affected by secondary processes during the ascent of water to the surface that mainly derive from the deep and hot geothermal systems.

In order to evaluate the applicability of conventional geothermometric estimates, the chemical composition of the thermal waters was plotted on a cationic ternary diagram (Giggenbach, 1988) (Fig. 9b). The majority of the samples fall in the immature waters field, and therefore, they have to be considered unsuitable for geothermometric estimations. Much fewer samples plot in the partial equilibrium field, while only one sample (Amplas 2) falls above the full equilibrium line. The latter refers to water in which an abundant $\mathrm{CH}_{4}$-rich gas phase was bubbling (Li Vigni et al., 2021). Waters interacting with $\mathrm{CH}_{4}$ are often characterised by a strong $\mathrm{Mg}$ depletion either because they are mixed with oil field brines (Kharaka \& Mariner, 1989) or with hyperalkaline water (Bruni et al., 2002; Cipolli et al., 2004).

The only samples that plot on or very close to the full equilibrium line are those taken from geothermal exploration wells at Milos (well M2-Koutroupis, 1992) and Nisyros (well $\mathrm{N}_{2}$-Koutroupis, 1992; Chiodini et al., 1993). The estimated temperatures nearly correspond to that measured at Milos $\left(318{ }^{\circ} \mathrm{C}\right.$-Liakopoulos et al., 1991) or are not so far from that measured at Nisyros $\left(290{ }^{\circ} \mathrm{C}\right.$-Chiodini et al., 1993). In the latter case, Chiodini et al. (1993) hypothesise a contamination by the seawater used to prepare the drilling mud.

Many of the partially equilibrated samples are close to the seawater point, and thus, the temperature of the reservoir could not be estimated due to the contamination with marine water. Only a few partially equilibrated samples mostly from Samothraki Island and Edipsos area may be considered reliable indicating temperatures up to $240-260{ }^{\circ} \mathrm{C}$ (Geotrisi). All these sites were selected and compared to the temperatures obtained from other geothermometric equations using the software Solute Geothermometers (SolGeo-Verma et al., 2008), which estimates the minimum temperature of the aquifer by comparing thirty-five geothermometric equations (Fig. 10a). The geothermometric estimations made with this software are based on the solute concentrations of the sampled waters. Many empirical geothermometric equations have been proposed by different researchers during the years and have been grouped together in this program. Most of them are based on cationic contents of the waters: 13 equations are based on the $\mathrm{Na}^{+}$and $\mathrm{K}^{+}$ contents of the waters, 3 on $\mathrm{K}^{+}$and $\mathrm{Mg}^{2+}, 2{\mathrm{on} \mathrm{Li}^{+}}^{+}$ and $\mathrm{Mg}^{2+}, 5$ on $\mathrm{Na}^{+}$and $\mathrm{Li}^{+}, 3$ on $\mathrm{Na}^{+}, \mathrm{K}^{+}$and $\mathrm{Ca}^{2+}$, 1 on $\mathrm{Na}^{+}, \mathrm{K}^{+}$and $\mathrm{Mg}^{2+}, 2$ on $\mathrm{Na}^{+}, \mathrm{K}^{+}, \mathrm{Ca}^{2+}$ and $\mathrm{Mg}^{2+}$ and finally 7 are silica geothermometers based on the $\mathrm{SiO}_{2}$ content. For the references of these geothermometers, we refer to the paper of Verma et al. (2008) while the formulas are included as supplementary material (Table S2).

As generally happens, the equations do not give back a unique temperature, but a wide range. The $\mathrm{Na}-$ $\mathrm{K}$ geothermometers show mostly the highest temperatures of reservoirs, with up to about $40{ }^{\circ} \mathrm{C}$ differences. On the contrary, $\mathrm{Li}-\mathrm{Mg}-\mathrm{K}$ and $\mathrm{Na}-\mathrm{Li}$ geothermometers present the lowest results; sometimes below the outlet temperature of the spring. It should be mentioned that the $\mathrm{Na}-\mathrm{K}$ geothermometers are considered the most reliable because less affected by mixing with shallow waters and degassing (Pope et al., 1987).

Excluding geothermometers giving estimations at or below the emergence temperature, the narrowest range is shown at thermal waters with estimated temperatures below $120{ }^{\circ} \mathrm{C}$ (Fig. 10a) and comprise samples from central Greece (Soulanta, Platystomo 


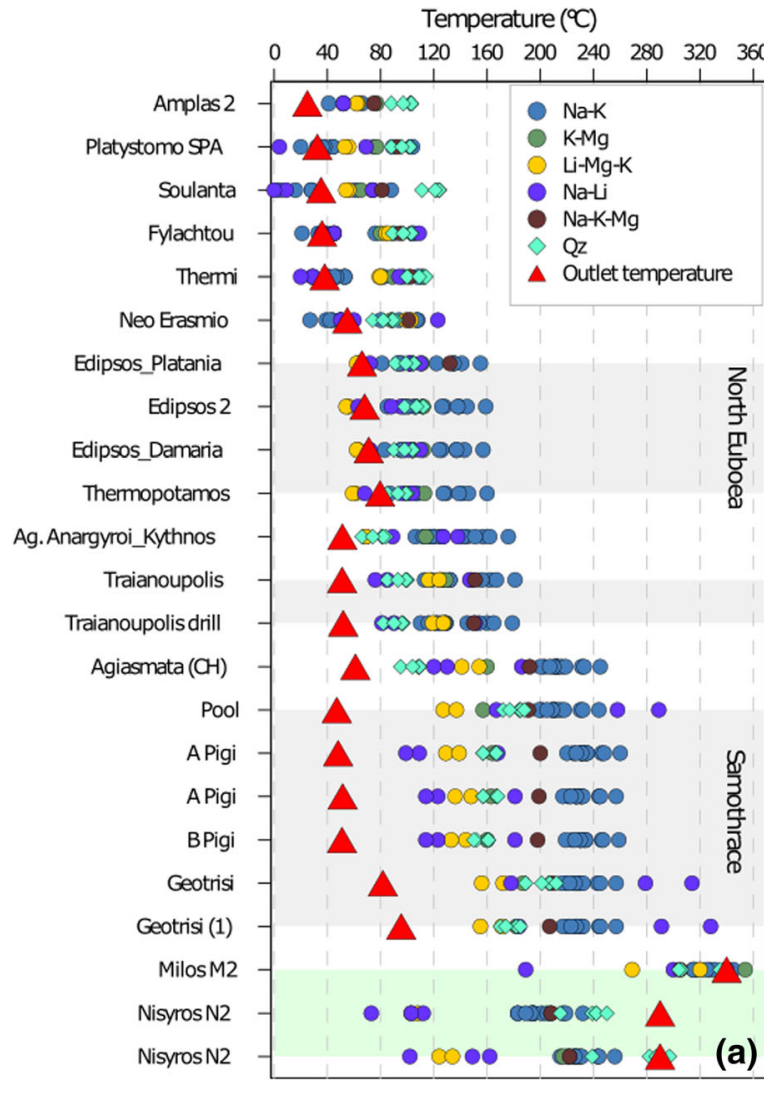

Fig. 10 a Results of the geothermometric estimations made with the computer program SolGeo (Verma et al., 2008) on selected samples that plotted in the partial equilibration field of the Giggenbach diagram of Fig. 9. b Thermal waters plotted on

SPA and Amplas2) and from northeastern Greece (Thermi, Neo Erasmio and Fylachtou).

A few sites gave $\mathrm{Na}-\mathrm{K}$ estimations up to 160-180 ${ }^{\circ} \mathrm{C}$ (Fig. 10a) indicating an important geothermal potential for the area of Edipsos (Northern Evia Island), Traianoupolis (Thrace) and Agioi Anargyroi (Kythnos Island). Only two areas gave estimations above $200{ }^{\circ} \mathrm{C}$ and up to $250{ }^{\circ} \mathrm{C}$ : the areas of Therma on Samothraki Island and of Agiasmata on Chios Island. For these systems, further studies should ascertain if they might be used also for electricity production.

To support this hypothesis, Fig. 10b evidences a correspondence among thermal springs and heat flux. The majority of studied thermal springs are located in areas with heat flux higher of $60 \mathrm{~mW} / \mathrm{m}^{2}$, while the highest values of temperature obtained from geothermometric estimation correspond to areas with elevated heat flow $\left(>80 \mathrm{~mW} / \mathrm{m}^{2}\right)$. The maxima of heat flux

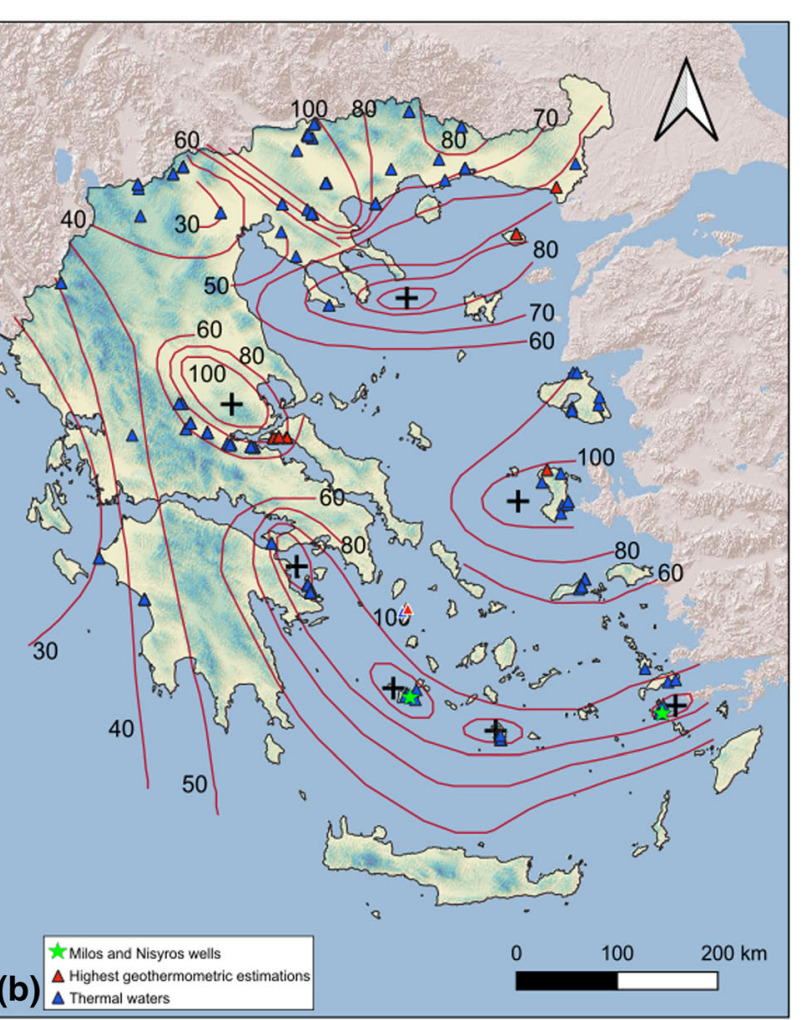

heat flow map $\left(\mathrm{mW} / \mathrm{m}^{2}\right)$ (Fytikas \& Kolios, 1979); red triangular indicates the highest estimated temperatures from geothermometric equations

$\left(>120 \mathrm{~mW} / \mathrm{m}^{2}\right.$ ), found along the SAAVA, do not show thermal springs with high measured temperature or high geothermometric estimates. This does not mean that no high-temperature geothermal system is present, but only that its impermeable seal is very efficient. As previously mentioned, in fact, two highenthalpy geothermal systems have been ascertained on the islands of Milos and Nisyros by explorative drillings. The geothermometric estimates made with the composition of the captured waters gave results closely resembling the measured temperature in the case of Milos (Fig. 10a). In the case of Nisyros, the close correspondence between estimation and measured value is found only for the silica geothermometer (Fig. 10a), which is less influenced by the contamination of the seawater used for the drilling mud (Chiodini et al., 1993). 
Tectonic structures as a fluid carrier

After studying the gas emissions of Greece, Daskalopoulou et al. (2018a) noticed a connection between lithological facies and dominant gas components. Particularly, the sedimentary regime of $\mathrm{EH}$, where hydrocarbon deposits are present, yield that $\mathrm{CH}_{4}$ and $\mathrm{N}_{2}$ are the dominant gas species in the area. On the other hand, $\mathrm{CO}_{2}$ is the principal gas component in $\mathrm{IH}$ and $\mathrm{HH}$, where intrusive and metamorphic formations prevail. On the basis of the geographical distribution of the gases, a similar behaviour between $\mathrm{CO}_{2}$ concentrations and $R_{\mathrm{C}} / R_{\mathrm{A}}$ ratios is noticed (Daskalopoulou et al., 2018a, 2019a). This reflects increasing $\mathrm{CO}_{2}$ and $R_{\mathrm{C}} / R_{\mathrm{A}}$ values in areas characterised by thin crust, elevated heat flow values, Plio-Quaternary volcanic activity and deep routed extensional or transtensional regional faults (Fig. 2b) (Daskalopoulou et al., 2019a); VA displays a higher mantle contribution for both $\mathrm{CO}_{2}$ and $\mathrm{He}$ with respect to $\mathrm{EH}$ that present an important crustal input (Daskalopoulou et al., 2019a).

As faults create a permeable pathway for gases to ascend (Wang \& Jaffe, 2004), special attention was given to places with complex tectonics. In northern Greece, the Strymonas Fault System is controlling the tectonics. In this area, gases collected from thermal waters, present an up to $15 \%$ mantle contribution for He (considering a MORB end-member). This is likely caused due to the U- and Th-rich minerals (i.e. zircon, apatite etc.-Wüthrich, 2009) of the granitoids present in this area; the decay of $\mathrm{U}$ and $\mathrm{Th}$ produces ${ }^{4} \mathrm{He}$ thereafter depleting the $\mathrm{R} / \mathrm{R}_{\mathrm{A}}$ values. Gases collected from the thermal waters of Euboea and Samothraki are found in the Grecian Shear Zone (propagation of the NAF towards the Hellenic mainland-Şengör, 1979). According to various authors (Güleç \& Hilton, 2006; Güleç et al., 2002; Mutlu et al., 2008), almost more than $50 \%$ of the He along some sections NAF derives from the mantle, hence $R / R_{\mathrm{A}}$ values are expected to be enriched in mantle He. Gases collected from the cold waters of Corinth Gulf are generally dominated by $\mathrm{CH}_{4}$ and $\mathrm{N}_{2}$ and the associated He shows always $R / R_{\mathrm{A}}$ values typical to pure crustal origin (Pik \& Marty, 2009). The same authors explained that the fault system is not connected in depth with zones in which mantle $\mathrm{He}$ can be trapped or that reaches the lower crust allowing the uprise of mantle fluids. It is worth mentioning that in the western part of the graben system (Saronikos gulf), where it meets the SAAVA, the Quaternary volcanic activity of Sousaki and Methana allowed $\mathrm{CO}_{2}$-rich fluids to reach the surface.

The above described extensional and transtensional deep regional tectonic structures, which are permeable pathways to the earth's surface for mantle or deep crustal fluids, allow also deep circulation of groundwater creating the conditions for the formation of small hydrothermal systems. In the case of the presence of an important heat source, along such tectonic structures some greater or higher temperature hydrothermal systems may form. This is the case of both Samothraki island and Edipsos (Fig. 10b) where the heat source is a Ternary granitic intrusion in the former case (Dotsika, 2012) and a Quaternary volcanic system in the latter (D'Alessandro et al. 2014).

\section{Conclusions}

Thermo-mineral waters in Greece are strongly controlled by the geologic and geodynamic setting that characterises the area where they are found. On the basis of $\mathrm{pH}$, hyperalkaline $\mathrm{Ca}-\mathrm{OH}$-type waters were identified in the ophiolitic sequences of Argolida and Othrys, while acidic waters were documented on islands located along the SAAVA. The former group represents the evolution of waters in deep serpentinised ultramafic aquifers in conditions closed to the atmosphere, while the latter highlights the impact of the volcanic/geothermal degassing on the waters. Based on their temperature, the remaining samples were subdivided into cold and thermal. Cold waters found in the northern part of Greece showed high $p \mathrm{CO}_{2}$ values and were characterised by $\mathrm{Ca}-\mathrm{HCO}_{3}$ composition. Carbon dioxide dissolution resulted in slightly acidic waters with elevated bicarbonate content. Saturation or oversaturation in the carbonate minerals is not common in this group. Few water samples with intermediate $p \mathrm{CO}_{2}$ were saturated, while the lack of equilibrium with carbonate minerals underscored the importance of $\mathrm{CO}_{2}$ dissolution. Cold waters collected in hydrocarbon-prone areas of western Greece presented low $p \mathrm{CO}_{2}$ and were close to equilibrium with the main carbonate minerals suggesting that the petrological regime (sedimentary limestones) governs the equilibrium of the dissolved carbonate species. On the other hand, thermal waters were seemingly controlled by the high heat flow 
values and the low crustal thickness. Their chemical composition was strongly influenced by mixing processes between meteoric water and seawater. Geothermometry was applicable only in few partially equilibrated waters suggesting reservoir temperatures from 80 to $260{ }^{\circ} \mathrm{C}$ with the most elevated values (between 200 and $260{ }^{\circ} \mathrm{C}$ ) being found in two islands of the eastern Aegean Sea (Samothraki and Chios).

This extensive dataset represents an almost complete catalogue of hydrogeochemical data on thermomineral waters of the whole Greece. This dataset has been gathered for over 15 years by the same research group and analysed in the same laboratory ensuring a good analytical uniformity. This database represents therefore a good basis for future studies on the thermomineral waters of this country.

Acknowledgements We kindly acknowledge all the Greek colleagues that helped us either in the field or with precious information about the sampling sites. Among them, we remember K. Athanasoulis, E. Dotsika, N. Lambrakis, S. Karakatsanis, K. Katsanou, N. Kolios, M. Margaritopoulos, G. Michas, G. Papadakis and M. Xenakis. Precious help either in the field or in the laboratory came also from S. Bellomo, C. Bruno, L. Brusca, G. Capasso, S. Francofonte, F. Grassa, M. Liotta, M. Minio, Y. Oliveri, F. Plicanti, V. Prano, A. Sollami, G. Volpicelli. We are also extremely grateful to all the owners, managers, public officers and employees, who gave us access to and precious information about the sampling points and/or helped us in the sampling operations. We are indebted to two anonymous reviewers whose insightful comments helped us to improve this paper.

Author contributions WD and KK conceived and designed the study; LLV, KD and WD wrote the first draft; all authors participated in the sampling campaigns, elaborated and interpreted the data and critically revised the manuscript.

Funding Open access funding provided by Istituto Nazionale di Geofisica e Vulcanologia within the CRUI-CARE Agreement. No specific funding was received for conducting this study. We acknowledge the support of Istituto Nazionale di Geofisica e Vulcanologia for all the analyses made for free in their laboratories.

Data availability All data are included in the supplementary material as Excel spread sheet.

\section{Declarations}

Conflict of interest The authors declare no conflicts of interest.

Consent to participate All authors have read and agreed with their participation.
Consent to publish All authors have read and agreed to the published version of the manuscript.

Open Access This article is licensed under a Creative Commons Attribution 4.0 International License, which permits use, sharing, adaptation, distribution and reproduction in any medium or format, as long as you give appropriate credit to the original author(s) and the source, provide a link to the Creative Commons licence, and indicate if changes were made. The images or other third party material in this article are included in the article's Creative Commons licence, unless indicated otherwise in a credit line to the material. If material is not included in the article's Creative Commons licence and your intended use is not permitted by statutory regulation or exceeds the permitted use, you will need to obtain permission directly from the copyright holder. To view a copy of this licence, visit http://creativecommons.org/licenses/by/4.0/.

\section{References}

Andritsos, N., Dalambakis, P., Arvanitis, A., Papachristou, M., \& Fytikas, M. (2015). Geothermal developments in Greece-Country update 2010-2014. In: Proceedings World Geothermal Congress 2015. Melbourne, Australia, 19-25.

APHA, AWWA, WEF. (2005). Standard methods for the examination of water and wastewater, 21 st ed., American Public Health Association, Washington D.C., U.S.A.

Argiriou, A. A., \& Lykoudis, S. P. (2006). Isotopic composition of precipitation in Greece. Journal of Hydrology, 327, 486-495.

Athanasoulis, K., Vakalopoulos, P., Xenakis, M., Persianis, D., \& Taktikos, S. (2009). Periodic monitoring of spa sources of Greece. Project Report "Integrated quantitative and qualitative study of the thermomineral waters of the country" Institute of Geological and Mineral Exploration (IGME) Athens (in Greek)

Barnes, I., Lamarche, V. C., \& Himmelberg, G. (1967). Geochemical evidence of present-day serpentinization. Science, 159, 830-832.

Brombach, T., Caliro, S., Chiodini, G., Fiebig, J., Hunziker, J., \& Raco, B. (2003). Geochemical evidence for mixing of magmatic fluids with seawater, Nisyros hydrothermal system, Greece. Bulletin of Volcanology, 65(7), 505-516.

Bruni, J., Canepa, M., Chiodini, G., Cioni, R., Cipolli, F., Longinelli, A., Marini, L., Ottonello, G., \& Vetuschi Zuccolini, M. (2002). Irreversible water-rock mass transfer accompanying the generation of the neutral, $\mathrm{Mg}-\mathrm{HCO}_{3}$ and high-pH, Ca-OH spring waters of the Genova province, Italy. Applied Geochemistry, 17, 455-474.

Chiodini, G., Cioni, R., Leonis, C., Marini, L., \& Raco, B. (1993). Fluid geochemistry of Nisyros Island, Dodecanese, Greece. Journal of Volcanology and Geothermal Research, 56, 95-112.

Chiodini, G., Frondini, F., \& Ponziani, F. (1995). Deep structures and carbon dioxide degassing in Central Italy. Geothermics, 24, 81-94. 
Chiodini, G., Cioni, R., Di Paola, G. M., Dotsika, E., Fytikas, M., Guidi, M., Leonis, C., Lyberopoulou, V., Magro, G., Marini, L., Meletidis, S., Michelot, J. L., Poutoukis, D., Raco, B., Russo, M., Virgili, G. (1998). Geochemistry of Santorini fluids, European Commission. Volcanic risk. The European laboratory volcanoes. In: R. Casale, M. Fytikas, G. Sigvaldasson, G. Vougioukalakis (Eds.), Proceedings of the Second Workshop. Santorini, Greece 2-4 May 1996, EUR 18161 EN,193-232.

Cipolli, F., Gambardella, B., Marini, L., Ottonello, G., \& Vetuschi Zuccolini, M. (2004). Geochemistry of high-pH waters from serpentinites of the Gruppo di Voltri (Genova, Italy) and reaction path modeling of $\mathrm{CO}_{2}$ sequestration in serpentinite aquifers. Applied Geochemistry, 19, 787-802.

Clayton, R. N., O’Neil, J. R., \& Mayeda, T. K. (1972). Oxygen isotope exchange between quartz and water. Journal of Geophysical Research, 77, 3057-3067.

Craig, H. (1961). Isotopic variation in meteoric waters. Science, 133, 1702-1703.

D’Alessandro, W., Brusca, L., Kyriakopoulos, K., Michas, G., \& Papadakis, G. (2009). Hydrogen sulphide as a natural air contaminant in volcanic/geothermal areas: The case of Sousaki, Corinthia (Greece). Environmental Geology, 57(8), 1723-1728.

D’Alessandro, W., Bellomo, S., Brusca, L., Karakazanis, S., Kyriakopoulos, K., \& Liotta, M. (2011). The impact on water quality of the high carbon dioxide contents of the groundwater in the area of Florina (N. Greece). In: Lambrakis, N., Stournaras, G., Katsanou, K. (Eds.), Advances in the Research of Aquatic Environment, Springer, Berlin, Germany, Vol. 2, 135-143

D’Alessandro, W., Brusca, L., Kyriakopoulos, K., Michas, G., \& Papadakis, G. (2008). Methana, the westernmost active volcanic system of the south Aegean arc (Greece): Insight from fluids geochemistry. Journal of Volcanology and Geothermal Research, 178, 818-828.

D’Alessandro, W., Brusca, L., Kyriakopoulos, K., Bellomo, S., \& Calabrese, S. (2014). A geochemical traverse along the "Sperchios Basin-Evoikos Gulf" Graben (Central Greece): Origin and evolution of the emitted fluids. Marine and Petroleum Geology, 55, 295-308.

D’Alessandro, W., Bellomo, S., Brusca, L., Kyriakopoulos, K., Calabrese, S., \& Daskalopoulou, K. (2017). The impact of natural and anthropogenic factors on groundwater quality in an active volcanic/geothermal system under semi-arid climatic conditions: The case study of Methana peninsula (Greece). Journal of Geochemical Exploration, 175, 110-119.

D’Alessandro, W., Daskalopoulou, K., Calabrese, S., \& Bellomo, S. (2018). Water chemistry and abiogenic methane content of a hyperalkaline spring related to serpentinization in the Argolida ophiolite (Ermioni, Greece). Special issue on gas geochemistry. In: Zhang S. and Yüce G. (Eds.), Marine and Petroleum Geology 89, 185-193.

Daskalaki, P., \& Voudouris, K. (2008). Groundwater quality of porous aquifers in Greece: A synoptic review. Environmental Geology, 54, 505-513.

Daskalopoulou, K., Calabrese, S., Grassa, F., Kyriakopoulos, K., Parello, F., Tassi, F., \& D’Alessandro, W. (2018a). Origin of methane and light hydrocarbons in natural fluid emissions: A key study from Greece. Chemical Geology, 479, 286-301.

Daskalopoulou, K., Gagliano, A. L., Calabrese, S., Longo, M., Hantzis, K., Kyriakolpoulos, K., \& D'Alessandro, W. (2018b). Gas geochemistry and $\mathrm{CO}_{2}$ output estimation of the Island of Milos, Greece. Journal of Volcanology and Geothermal Research, 365, 13-22. https://doi.org/10. 1016/j.jvolgeores.2018.10.003

Daskalopoulou, K., Calabrese, S., Gagliano, A. L., \& D'Alessandro, W. (2019a). Estimation of the geogenic carbon degassing of Greece. Applied Geochemistry, 106, 60-74.

Daskalopoulou, K., Gagliano, A. L., Calabrese, S., Li Vigni, L., Longo, M., Kyriakopoulos, K., Pecoraino, G., \& D'Alessandro, W. (2019b). Degassing at the volcanic/geothermal system of Kos (Greece): geochemical characterization of the released gases and $\mathrm{CO}_{2}$ output estimation. Geofluids, Vol 2019, Article ID 3041037. https://doi.org/10.1155/2019/3041037

Dolgorjav, O. (2009) Geochemical characterization of thermal fluids from the Khangay area, Central Mongolia. Geothermal training programme reports, Orkustofnun, Grensásvegur, 9.

Dotsika, E. (2012). Isotope and hydrochemical assessment of the Samothraki Island geothermal area, Greece. Journal of Volcanology and Geothermal Research, 233-234, 18-26.

Doutsos, T., Koukouvelas, I. K., \& Xypolias, P. (2006). A new orogenic model for the external Hellenides. Geological Society, London, Special Publications, 260, 507-520. https://doi.org/10.1144/GSL.SP.2006.260.01.21

Duriez, A., Marlin, C., Dotsika, E., Massult, M., Noret, A., \& Morel, J. L. (2008). Geochemical evidence of seawater intrusion into a coastal geothermal field of central Greece: Example of the Thermopylae system. Environmental Geology, 54, 551-564. https://doi.org/10.1007/s00254007-0857-9

Evans, B. W., Hattori, K., \& Baronnet, A. (2013). Serpentinite: What, why, where? Elements, 9, 99-106.

Fytikas, M. (1988). Geothermal situation in Greece. Geothermics, 17, 549-556.

Fytikas, M., \& Kolios, N. (1979). Preliminary heat flow map of Greece. In V. Cermak \& L. Rybach (Eds.), Terrestrial heat flow in Europe (pp. 197-205). Springer-Verlag.

Fytikas, M., Innocenti, F., Manetti, P., Mazuoli, R., Peccerilo, A., \& Villari, L. (1984). Tertiary to quaternary evolution of the volcanism in Aegean Sea. In: Dixon J. E., Robertson, A. H. F. (Eds.), The geological evolution of the Eastern Mediterranean, vol 17, 687-699. (Geological Society of London Special Publications).

Fytikas, M., Margomenou-Leonidopoulou, G., \& Cataldi, R. (1999). Geothermal energy in ancient Greece: From mythology to late antiquity. In: Stories from a Heated Earth. Geothermal Resources Council and IGA, California.

Fytikas, M., Andritsos, N, Dalabakis, P., \& Kolios, N. (2005). Greek geothermal update 2000-2004. In: Proceedings World Geothermal Congress 2005, Antalya, Turkey, 24-29 Apr 2005.

Gat, J. R., \& Carmi, H. (1971). Evolution of the isotopic composition of atmospheric waters in the Mediterranean Sea area. Journal of Geophysical Research, 75, 3039-3040. 
Giggenbach, W. F. (1988). Geothermal solute equilibria. Derivation of $\mathrm{Na}-\mathrm{K}-\mathrm{Mg}-\mathrm{Ca}$ geoindicators. Geochimica et Cosmochimica Acta, 52(12), 2749-2765.

Giggenbach, W. F. (1991). Chemical techniques in geothermal exploration. In F. D'Amore (Ed.), Application of geochemistry in geothermal reservoir development (pp. 252-270). UNITAR/UNDP.

Gilhooly, W. P., III., Fike, D. A., Druschel, G. K., Kafantaris, F. C. A., Price, R. E., \& Amend, J. P. (2014). Sulfur and oxygen isotope insights into sulfur cycling in shallow-sea hydrothermal vents, Milos, Greece. Geochemical Transactions, $15,12$.

Grigoriadis, V., Tziavos, I., Tsokas, G., \& Stampolidis, A. (2016). Gravity data inversion for Moho depth modeling in the Hellenic area. Pure and Applied Geophysics, 173, 1223-1241. https://doi.org/10.1007/s00024-015-1174-y

Güleç, N., Hilton, D. R., \& Mutlu, H. (2002). Helium isotope variations in Turkey: Relationship to tectonics, volcanism and recent seismic activities. Chemical Geology, 187, 129-142.

Güleç, N. H., \& Hilton, D. R., (2006). Helium and heat distribution in western Anatolia, Turkey: Relationship to active extension and volcanism. In: Dilek, Y., Pavlides, S., (Eds.), Postcollisional tectonics and magmatism in the Mediterranean region and Asia. In: Geological Society of America Special Papers, 409, 305-319.

Håland, E. J. (2009). Water sources and the sacred in modern and ancient Greece and beyond. Water History, 1, 83-108.

Kallioras, A., \& Marinos, P. (2015). Water resourches assessment and management of karst aquifer systems in Greece. Environmental Earth Sciences, 74, 83-100.

Karakatsanis, S., Koukouzas, N., Pagonas, M., \& Zelilidis, A. (2007). Preliminary sedimentological results indicate a new detailed stratigraphy for the Florina sedimentary basin and relate them with $\mathrm{CO}_{2}$ presence. Bulletin of the Geological Society of Greece, 40. In: Proceedings of 11th International Congress, Athens, May 2007.

Karolyte, R., Serno, S., Johnson, G., \& Gilfillan, S. M. V. (2017). The influence of oxygen isotope exchange between $\mathrm{CO}_{2}$ and $\mathrm{H}_{2} \mathrm{O}$ in natural $\mathrm{CO}_{2}$-rich spring waters: Implications for geothermometry. Applied Geochemistry, 84, 173-186.

Kaya, E., Zarrouk, S. J., \& O'Sullivan, M. J. (2011). Reinjection in geothermal fields: A review of worldwide experience. Renewable and Sustainable Energy Reviews, 15, 47-68.

Kharaka, Y. K., \& Mariner, R. H. (1989). Chemical geothermometers and their application to formation waters from sedimentary basins. In: Naeser, N. D., and McCollon, T. H. (Eds.), Thermal history of sedimentary basins, Springer, pp. 99-117.

Koutroupis, N. (1992). Update of geothermal energy development in Greece. Geothermics, 21, 881-890.

Lambrakis, N., \& Kallergis, G. (2005). Contribution to the study of Greek thermal springs: Hydrogeological and hydrochemical characterized and origin of the thermal waters. Hydrogeology Journal, 13, 506-521.

Landerer, X. (1843). Beschreibung der heilquellen Griechenlands. Nuremberg.

Langelier, W., \& Ludwig, H. (1942). Graphical methods for indicating the mineral character of natural waters. $J W W A$, $34,335-352$.
Le Pichon, X., Sengor, A. M. C., Demirbag, E., Rangin, C., Imren, C., Armijo, R., Gorur, N., Cagatay, N., Mercier de Lépinay, M., Meyer, B., Saatcilar, B., \& Tok, B. (2001). The active main Marmara fault. Earth and Planetary Science Letters, 192, 595-616.

Liakopoulos, A., Katerinopoulos, A., Markopoulos, T., \& Boulegue, J. (1991). A mineralogical petrographic and geochemical study of samples from wells in the geothermal field of Milos island (Greece). Geothermics, 20, 237-256.

Li Vigni, L., Daskalopoulou, K., Calabrese, S., Parello, F., \& D'Alessandro, W. (2021). Geochemical characterisation of the alkaline and hyperalkaline groundwater in the Othrys Ophiolite Massif, central Greece. Italian Journal of Geosciences, 140(1), 42-56. https://doi.org/10.3301/IJG.2020

Machel, H. G. (2001). Bacterial and thermochemical sulfate reduction in diagenetic settings-old and new insights. Sedimentary Geology, 140, 143-175.

Marini, L., \& Fiebig, J. (2005). Fluid geochemistry of the magmatic-hydrothermal system of Nisyros (Greece). Mémoire De Géologie, 44, 192.

Marini, L., Gambardella, B., Principe, C., Arias, A., Brombach, T., \& Hunziker, J. C. (2002). Characterization of magmatic sulfur in the Aegean island arc by means of the $\delta^{34} \mathrm{~S}$ values of fumarolic $\mathrm{H}_{2} \mathrm{~S}$, elemental $\mathrm{S}$, and hydrothermal gypsum from Nisyros and Milos islands. Earth Planetary Science Letters, 200, 15-31.

McClusky, S., Balassanian, S., Barka, A., Demir, C., Ergintav, S., Georgiev, I., Gurkan, O., Hamburger, M., Hurst, K., Kahle, H., Kastens, K., Kekelidze, G., King, R., Kotzev, V., Lenk, O., Mahmoud, S., Mishin, A., Nadariya, M., Ouzounis, A., ... Veis, G. (2000). Global Positioning System constraints on plate kinematics and dynamics in the Eastern Mediterranean and Caucasus. Tectonophysics, 105, 5695-5719.

Mendrinos, D., Choropanitis, I., Polyzou, O., \& Karytsas, C. (2010). Exploring for geothermal resources in Greece. Geothermics, 39, 124-137. https://doi.org/10.1016/j. geothermics.2009.11.002

Mercier, J. L. (1981). Extensional-compressional tectonics associated with the Aegean Arc: Comparison with the Andean Cordillera of south Peru-north Bolivia. Philosophical Transactions of the Royal Society London, A300, 337-355.

Meyback, M. (1987). Global chemical weathering of surficial rocks estimated from river-dissolved loads. American Journal of Science, 287, 401-428.

Minissale, A., Duchi, V., Kolios, N., \& Totaro, G. (1989). Geochemical characteristics of Greek thermal springs. Journal of Volcanology and Geothermal Research, 39, $1-16$.

Minissale, A., Duchi, V., Kolios, N., Nocenti, M., \& Verruchi, C. (1997). Chemical patterns of the thermal aquifers in the volcanic Islands of the Aegean Arc, Greece. Geothermics, 26(4), 501-518.

Mountrakis, D.M. (1985). Geology of Greece. University Studio Press, Thessaloniki, pp. 207 (in Greek).

Mountrakis, D.M. (2010). Geology and geotectonic evolution of Greece. University Studio Press, Thessaloniki, pp. 374 (in Greek). 
Mutlu, H., Güleç, N., \& Hilton, D. R. (2008). Helium-carbon relationships in geothermal fluids of western Anatolia, Turkey. Chemical Geology, 247, 305-321.

Nordstrom, D. K., McCleskey, R. B., \& Ball, J. W. (2009). Sulfur geochemistry of hydrothermal waters in Yellowstone National Park: IV acid-sulfate waters. Applied Geochemistry, 24, 191-207.

National Touring Organisation, NTO. (1966). Bathing sites and curative springs. National Printing Office, Athens. (In Greek, with extended summaries in French and English).

Palacas, J. G., Monopolis, D., Nicolaou, C. A., \& Anders, D. E. (1986). Geochemical correlation of surface and subsurface oils, western Greece. Organic Geochemistry, 10, 417-423.

Papachristou, M., Arvanitis, A., Mendrinos, D., Dalambakis, P., Karytsas, C., \& Andritsos, N. (2019). Geothermal Energy Use, Country Update for Greece (2016-2019). Proceedings of the European Geothermal Congress 2019, Den Haag, The Netherlands, 11-14 June 2019.

Papachristou, M., Voudouris, K., Karakatsanis, S., D’Alessandro, W., \& Kyriakopoulos, K. (2014). Geological setting, geothermal conditions and hydrochemistry of south and southeastern Aegean geothermal systems. In: Baba, A., Bundschuh, J., Chandrasekaram D. (Eds.), Geothermal Systems and Energy Resources: Turkey and Greece, Chapter 4, CRC Press - Taylor \& Francis Group

Parkhurst, D. I., \& Appelo, C. A. J. (1999). User guide to PHREEQC (Version 2)-a computer program for speciation, batch-reaction, one-dimensional transport, and inverse geochemical calculation. U. S. Geological Survey of Water Resource Investigation Report 99-4259, p. 310.

Pavlides, S., \& Caputo, R. (2004). Magnitude versus faults' surface parameters: Quantitative relationships from the Aegean. Tectonophysics, 380(3-4), 159-188.

Pavlides, S. B., \& Mountrakis, D. M. (1987). Extensional tectonics of northwestern Macedonia, Greece, since the late Miocene. Journal of Structural Geology, 9, 385-392.

Pavlides, S., Caputo, R., Sboras, S., Chatzipetros, A., Papathanasiou, G., \& Valkaniotis, S. (2010). The Greek catalogue of active faults and database of seismogenic sources. Bulletin of the Geological Society of Greece, 43(1), 486-494.

Pearce, JM (Ed.) (2004). Natural analogues for the geological storage of $\mathrm{CO}_{2}$. Final report of the Nascent project. British Geological Survey Technical Report, 122 pp.

Pe-Piper, G., \& Piper, D. J. W. (2002). The igneous rocks of Greece, the anatomy of an orogen. Beiträge zur regionalen Geologie der Erde 30, Gebrüder Bornträger, BerlinStuttgart.

Pe-Piper, G., \& Piper, D. J. W. (2006). Unique features of the Cenozoic igneous rocks of Greece. Geological Society of America, Special Paper, 409, 259-282.

Pertessis, M. (1937). Thermomineral Springs of Greece. Publication of the Geological Survey of Greece, n. 24. Athens (in Greek).

Pik, R., \& Marty, B. (2009). Helium isotopic signature of modern and fossil fluids associated with the Corinth rift fault zone (Greece): Implication for fault connectivity in the lower crust. Chemical Geology, 266, 67-75.
Pollack, H. N., Hurter, S., \& Johnson, J. R. (1993). Heat flow from the earth's interior: Analysis of the global data set. Reviews of Geophysics, 31, 267-280.

Pope, L. A., Hajash, A., \& Popp, R. K. (1987). An experimental investigation of the quartz, Na-K, Na-K-Ca geothermometers and the effects of fluid composition. Journal of Volcanology and Geothermal Research, 31, 151-161.

Rezaei, A., Javadi, H., Rezaeian, M., \& Barani, S. (2018). Heating mechanism of the Abgarm-Avaj geothermal system observed with hydrochemistry, geothermometry, and stable isotopes of thermal spring waters, Iran. Environmental Earth Sciences, 77, 635.

Rigakis, N., \& Karakitsios, V. (1998). The source rock horizons of the Ionian Basin (NW Greece). Marine and Petroleum Geology, 15, 593-617.

Şengör, A. M. C. (1979). The North Anatolian Transform Fault: Its age, offset and tectonic significance. Journal of Geological Society of London, 136, 269-282.

Sinclair, A. J. (1974). Selection of threshold values in geochemical data using probability graphs. Journal of Geochemical Exploration, 3, 129-149.

Singh, H., Chandrasekharam, D., Vaselli, O., Trupti, G., Singh, B., Lashin, A., \& Arifi, N. A. (2015). Physico-chemical characteristics of Jharkhand and West Bengal thermal springs along SONATA mega lineament, India. Journal of Earth System Science, 124(2), 419-430.

Taymaz, T., Jackson, J., \& McKenzie, D. (1991). Active tectonics of the north and central Aegean Sea. Geophysical Journal International, 106, 433-490.

Tsokas, G. N., \& Hansen, R. O. (1997). Study of the crustal thickness and the subducting lithosphere in Greece from gravity data. Journal of Geophysical Research, 102(B9), 585-597. https://doi.org/10.1029/97JB00730

van Hinsbergen, D. J. J., Hafkenscheid, E., Spakman, W., Meulenkamp, J. E., \& Wortel, R. (2005). Nappe stacking resulting from subduction of oceanic and continental lithosphere below Greece. Geology, 33(4), 325-328.

Verma, S. P., Pandarinath, K., \& Santoyo, E. (2008). SolGeo: A new computer program for solute geothermometers and its application to Mexican geothermal fields. Geothermics, 37, 597-621.

Vougioukalakis, G., Eleftheriadis, G., Christofides, G., Pavlides, S., Fytikas, M., \& Villa, I. (2004). Volcanological study of the Almopias Pliocene volcanic formations ( N Greece). In: Proceedings of the 5th International Symposium on Eastern Mediterranean Geology 3, 1318-1321.

Wang, S., \& Jaffe, P. R. (2004). Dissolution of a mineral phase in potable aquifers due to $\mathrm{CO}_{2}$ releases from deep formations. Effect of Dissolution Kinetics Energy Conversion and Management, 45, 2833-2848.

Wüthrich, E. D. (2009). Low temperature thermochronology of the northern Aegean Rhodope Massif. Doctor of Sciences Thesis, Swiss Federal Institute of Technology Zurich, Switzerland.

Publisher's Note Springer Nature remains neutral with regard to jurisdictional claims in published maps and institutional affiliations. 